\title{
1995年兵庫県南部地震の港湾被害に基づく 海岸護岸の照査基準に関する一考察
}

\author{
小泉 勝彦 1 ・ 一井 康二 2 ・曽根 照人 3 ・平井 俊之 4 ・村上 巧一 5 ・ 山中 稔 6 \\ 1正会員 国土交通省 四国地方整備局 高松港湾空港技調査事務所 \\ ( テ760-0017 香川県高松市番町一丁目6番1号住友生命高松ビル2階) \\ E-mail: koizumi-k88s3@mlit.go.jp \\ 2国際会員＼cjkstart関西大学教授 社会安全学部（广569-1098 大阪府高槻市白梅町7番1号） \\ E-mail: ichiik@kansai-u.ac.jp \\ 3 正会員＼cjkstart株式会社ニュージェック 港湾・海岸グループ（テ531-0074 大阪市北区本庄東2-3-20） \\ E-mail: sonekt@newjec.co.jp \\ 4正会員 株式会社ニュージェック 港湾・海岸グループ（テ531-0074 大阪市北区本庄東2-3-20） \\ E-mail: hiraits@newjec.co.jp \\ 5 正会員＼cjkstart株式会社ニュージェック 港湾・海岸グループ（†531-0074 大阪市北区本庄東2-3-20） \\ E-mail: murakamikc@newjec.co.jp \\ 6正会員 香川大学教授 工学部（干761-0396 高松市林町2217-20） \\ E-mail: yamanaka@eng.kagawa-u.ac.jp
}

\begin{abstract}
現在，港湾区域内の海岸保全施設の設計には，海岸保全施設の技術上の基淮・同解説1 および港湾の施 設の技術上の基準・同解説 2)に基づいた性能設計が導入されている. 文献1)では，目的達成性能の照查 〈処理基準〉として津波堤防の天端高についての記述があるが，水平変位に対する記述は見当たらない。 文献2)では，海岸保全施設の水平変位は，重力式係船岸の変形量を参照することができるとの規定がある のみである.このことから, 海岸護岸の性能設計に用いる水平変位に関寸る照査基準には研究の余地があ ると考えられる. 本研究では1995年兵庫県南部地震における神戸港の港湾被害を分析し, 海岸護岸の設計 地震に対する残留変形量を護岸天端幅の 2 倍とする照査基準を提案し, 実際の海岸護岸の改良事業に提案 した照査基準を適用した結果を報告する.
\end{abstract}

Key Words : seismic design, seawalls, tsunami, design example, liquefaction

\section{1. はじめに}

1995年兵庫県南部地震以降，港湾の分野におけるレ心゙ ル2地震動に対する変形量照査では，一井ら3)の研究をは じめとする解析結果が被災事例を良く説明したことから， ひずみ空間における多重せん断ばねモデルを用いた動的 変形解析怆よって施設の残留変形量を求めた上で，残 留変形量を変形量の限界值と比較することが行われてい る. 海岸護岸の設計においては, 長尾ら5が，護岸と岸 壁では求められる性能が異なりながら, 用いられている 設計法は基本的に違いが無いことを指摘した上で，護岸 の保持する性能について岸壁との比較などの観点から検 討し, 護岸の許容はらみ出し量は岸壁のはらみ出し許容 值と比較すると安全側であることを指摘している.
一方，平成23年の東日本大震災において発生した甚大 な津波被害を踏まえて, 海岸法や海岸保全施設の技術上 の基準を定める省令の改正などが行われた. 改正に当っ ては，減災機能を有する堤防等（粘り強い構造）の海岸 保全施設一の位置付け，水門・陸閘等の操作規則等の策 定等，海岸保全施設の維持・修䋨基準の策定，など新し い考え方が盛り込まれているの. しかし, 南海トラフ沿 いの地域のみならず，日本海側も含めた各地域において 大規模地震による津波対策は，喫緊の課題》となってい る. 海岸保全施設の技術上の基準については，東日本大 震災の教訓を踏まえた知見の蓄積を反映し, 設計津波を 生じさせる地震がレベル1地震動を超える強度の場合の 而震性能は設計津波の水位が地震後の天端高さを上回ら ないことなどを確認するものであることが明確にされて 
いる ${ }^{8)}$. しかし，海岸保全施設の技術上の基準・同解説1) では，港湾の施設の技術上の基準・同解説2)に記載され ている而震強化施設のレベル2地震動に対する変形量の

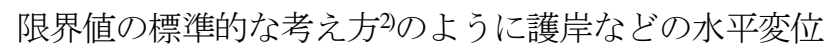
に対して残留変形量の限界值を定める記述は見当たらな い. 港湾の施設の技術上の基準・同解説2)においては, 海岸護岸のレベル2地震に対する変形量の標準的な限界 值は耐震強化岸壁のものが参考にできると記載されてい るが，海岸護岸そのものの変形量の限界值は定められて いない.これらのことから，設計津波に対する護岸の天 端高さについては照査基準が明確になっているが，海岸 護岸の残留水平変位に対する照査基準は明確になってい ないことがわかる.

1995年兵庫県南部地震の港湾被害においては，護岸等 の残留水平変位によって護岸の天端高さが実質的に低下 していたと考えられる被災事例など，多くの被災事例が ある.こういった被災事例に基づいて重力式海岸保全施 設の地震動に対する変形量の限界值を設定することは, 合理的な海岸護岸の性能照査を進める上で有意義である と考えられる.

本研究では，1995年兵庫県南部地震における港湾被害 を分析し, 設計地震後に残留する施設の最大水平変位に 対する照査基準を隣接する函塊との目地ずれに着目して 新しく提案し，四国地方整備局の海岸護岸の改良事業に 対して適用した改良断面を示す。加えて，施設の函塊間 の目地開きが生じると目地からの浸水が発生することか ら，函塊間の目地開きについても考察し，隣接する函塊 相互が，異なる角度で水平方向に回転することによって 生じる目地開き量を推定方法を提案する. さらに，目地 開き箇所からの浸水量を算定し, 目地からの浸水に関し ても本論文で示した手法が適用可能であることを示す.

\section{2. 設計地震に対する護岸の目地ずれ量の限界値}

\section{(1) 護岸の水平変位による天端高さの低下}

写真-1に, 文献9)より兵庫県南部地震での海岸護岸等 の被災例を示す．写真-1(a)が西部1工区護岸（長田西） の被災状況，(b)が東部4工区護岸（信号所）の被災状況， (c)が西魚崎地区物揚場(-4.0m)および護岸の被災状況であ る. (a)西部1工区護岸では, 「地震力により, 護岸本体 が海側に移動すると共に沈下も生じた.」と記載されて いる（文献9), p.144）。(b)東部4工区護岸では，「護岸が 地震力によって, 水平方向に2.3〜 2.9m海側に移動し, 併 せて $150 \mathrm{~cm}$ 程度沈下した（文献9), p.143）。」と記載され ている. (c)の西魚崎地区物揚場(-4.0m)護岸については, 文献9)には詳しい記述は無いが，文献10)の図-4.2.1.44〜 困-4.2.1.47(pp.381-383)に詳しい調査結果が記載されている. 写真-1(c)の護岸については15～44cm海側に移動，天端は 沈下している（文献10), p.229）と記載されている.

ここで，本研究で用いる用語について明確にしておく. 本研究では, 写真-1(a)に示すようなコンクリート函塊相 互の断面方向のずれを「目地ずれ」，写真-1(b)に示すよ うな施設法線方向に函塊の目地が広がることを「目地開 き」と呼称することとする.

写真-1(a)ではケーソンの海側への移動量がケーソン毎 に異なるために目地ずれが生じ，目地部分では施設の天 端高さが実質的に赤い矢印の高さまで下がっていること がわかる. 仮にこの状態で, 護岸天端の高さ（写真-1(a) 中のA，Bの高さ）の津波・高潮が襲来した場合，護岸 の天端高さは足りているが， $\triangle \mathrm{ABC}$ で近似される隙間か らの浸水が発生するものと考えられる. 写真-1(b)では, 目地ずれの量は定かでないが，目地開きが生じ，津波や 高潮の発生によって目地開き部分から背後地への浸水が 生じることが考えられる，写真-1(c)では，写真-1(a)で見 られたようなコンクリート函塊（本護岸においてはL型 ブロック）の海側への変位による目地部での護岸天端の 低下は見られず，目地開きも小さい。文献10)の 図-4.2.1.44を参照すると写真-1(c)中央部の目地部に相当 する箇所に「目地間詰工 $0.05 \mathrm{~m} 」 と の$ 記載があり, この 目地における上部工の目地開きは0.05mであったと考え られる.もし護岸のこの箇所が地震の被災後であっても 津波に対して安定を保つならば，地震後の津波による浸 水被害の抑制に役立つものと考えられる. したがって,

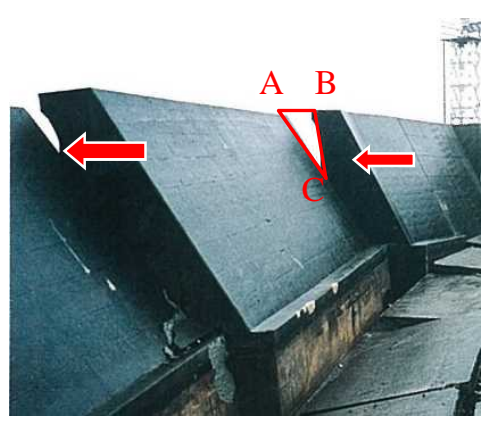

(a) 西武1工区護岸（長田西）

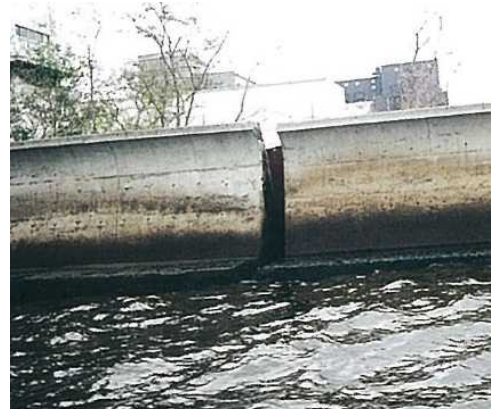

(b) 東部4工区護岸（信号所）

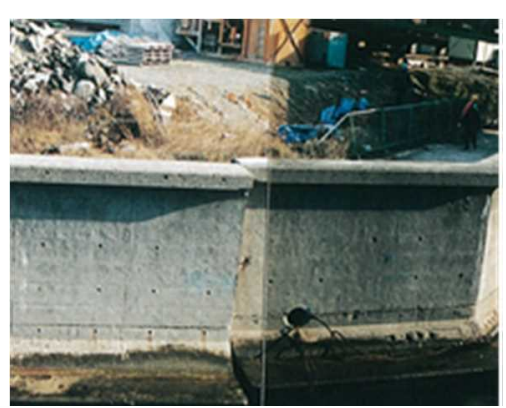

(c) 西魚崎地区物用場 $(-4.0 \mathrm{~m}) \cdot$ 護岸

写真-1 1995年兵庫県南部地震における護岸の被災例9) 
写真-1(b)のように目地開き部からの浸水量が大きいと想 定される場合には，目地開きからの浸水対策を考慮する 必要があるものと考えられる. ここで，具体的に目地開 きからの浸水対策の必要性の判断および目地開きからの 浸水防止対策工の設計に先立って, 目地開きを予測する 必要があるものと考えられる.

\section{（2）設計地震に対する護岸の目地ずれ量の限界値}

写真-1(a) と写真-1(c)を見比べてみる. 写真-1(a)の $\Delta$ $\mathrm{ABC}$ は, 中央の函塊と奥の函塊との水平方向の水平変位 差によって生じていることがわかる. この水平変位差が 小さくなるにしたがって, $\triangle \mathrm{ABC}$ むさくなり, やがて

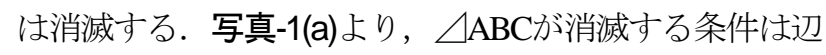
$\mathrm{AB}$ が0になることであると理解できる.このことから， 目地ずれの発生による実質的な天端高さの低下を防ぐた めには，図-1に示すように，護岸天端幅 $w$ が隣接函塊間 の最大目地ずれ量 $e_{\max }$ 以上であることが必要であると考 えられる.

一方で，比較的簡易な方法で目地開き量が想定できれ ば，そこからの浸水量を予測し，目地開きに対する浸水 防護措置の検討や排水構造の設計などにも用いることが できると考えられる，そこで，続く第3章では，既往の 地震被災事例のデータを用いて，目地ずれ量と目地開き 量の推定方法を検討し, 照査基淮を提案する.
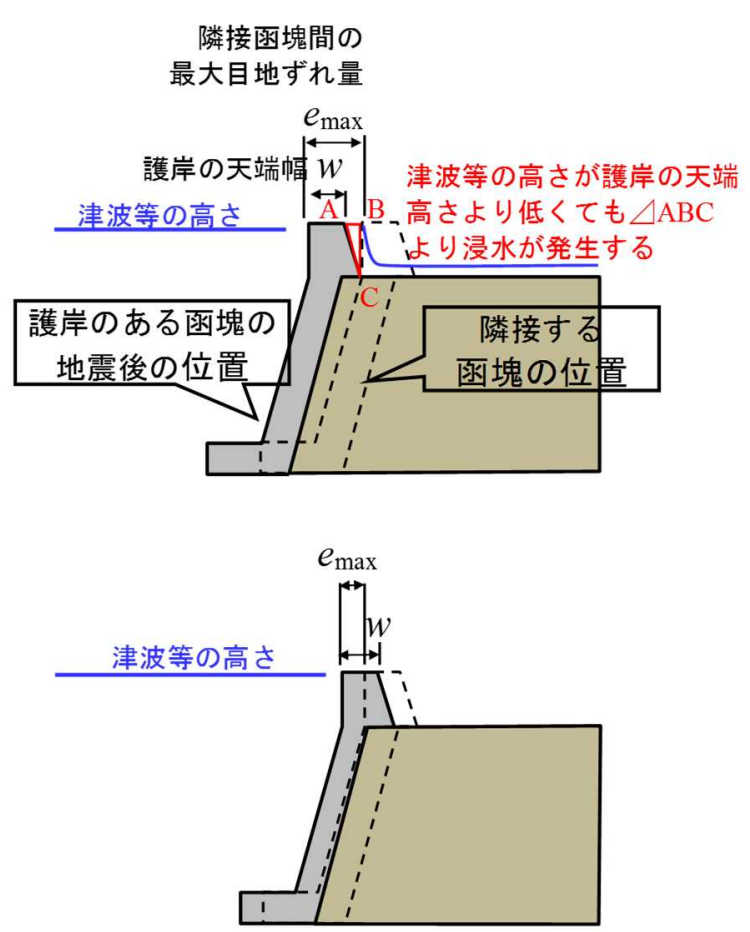

目地ずれによる護岸天端の低下が発生しない条件 護岸の天端幅 $w \geqq$ 隣接函塊間の最大目地ずれ量 $e_{\max }$

図-1 設計地震に対する護岸の目地ずれ量の限界值

\section{3. 設計地震に対する護岸の照査基準}

\section{(1) 本研究で用いた地震被害データ}

国内において海岸保全施設や港湾施設に大きな被害を 与えた地震の代表例は，1995年兵庫県南部地震と平成23 年 (2011年) 東北地方太平洋沖地震である. そして, 両 地震とも詳細な被害報告が出されている. しかし, 平成 23年東北地方太平洋沖地震の被害調査報告 ${ }^{11)}$ では, 施設 両端での水平変位を0としている施設がほとんどである. これは, 津波の被害が大きく, 被災前法線の特定が非常 に困難であったためであると考えられる。したがって, 文献11)では施設の水平変位を過小に記録している可能 性がある.このことから，本研究では1995年兵庫県南部 地震の港湾被害報告10の事例を用いて, 護岸の設計地震 に対する変形量の限界值の検討を行うこととした.

\section{（2）兵庫県南部地震における神戸港の港湾被害の特徵}

文献10)からコンクリート函塊式の係留施設及び護岸 について, 施設の水平変位と目地の開き量に着目して被 害状況を分析した。 その結果，本研究に関連する幾つか の特徴が見られた．このことから，まず，その特徵につ いて述べる。

図-2に，兵庫県南部地震における特徴的な港湾被害の 状況を文献10)より概略的に示す.

図-2(a)は，神戸港六甲アイランド地区- $4 \mathrm{~m}$ 物揚場(4), -12m岸壁W ZバースおよびZバース取付のケーソン断面 方向のケーソン毎の法線出入りとケーソン天端開きであ る. 図-2(a)は, 文献10)中で, 別々の図として示されて いた-4m物揚場(4)から-12m岸壁バース取り付けに至る7施 設の法線出入りおよび目地開き量について, 筆者らがつ なぎ合わせて一つの図にまとめたものである. 文献10) 中では，施設名を示寸番号が○囲みの数字で記載させて いるものがあるが, 本論文中では( )内の数值として示 す.したがって，-4m物揚場(4)の(4)は，文献10)中では, ○囲みの4と記載されている. 図中の四角枠囲いの中の 数值がケーソン番号であり, 一連の施設においては連番 となっている，文献10)においては，上部工の天端出入 とケーソン天端出入の実測值が記載されている. 加えて, ケーソン下端出入りがケーソン天端出入りとケーソンの 傾斜角から計算で求められている施設がある. 図-2(a)も そのような施設であり, 3 種類の法線出入を, 各々, 黒 （上部工天端出入り）, 青（ケーソン天端出入り），マ ゼンタ (ケーソン下端天端出入り) で示している. ケー ソン番号の上下の数值はケーソン天端の目地開きを $\mathrm{cm}$ 単位で示したものである. この施設の設計上のケーソン 目地間隔は $5 \mathrm{~cm}$ と想定されたので, ケーソン天端の目地 間隔が $5 \mathrm{~cm}$ 上回る箇所では上部工の目地開きが発生し ている可能性が高いと考えられる.このことから $5 \mathrm{~cm}$ 


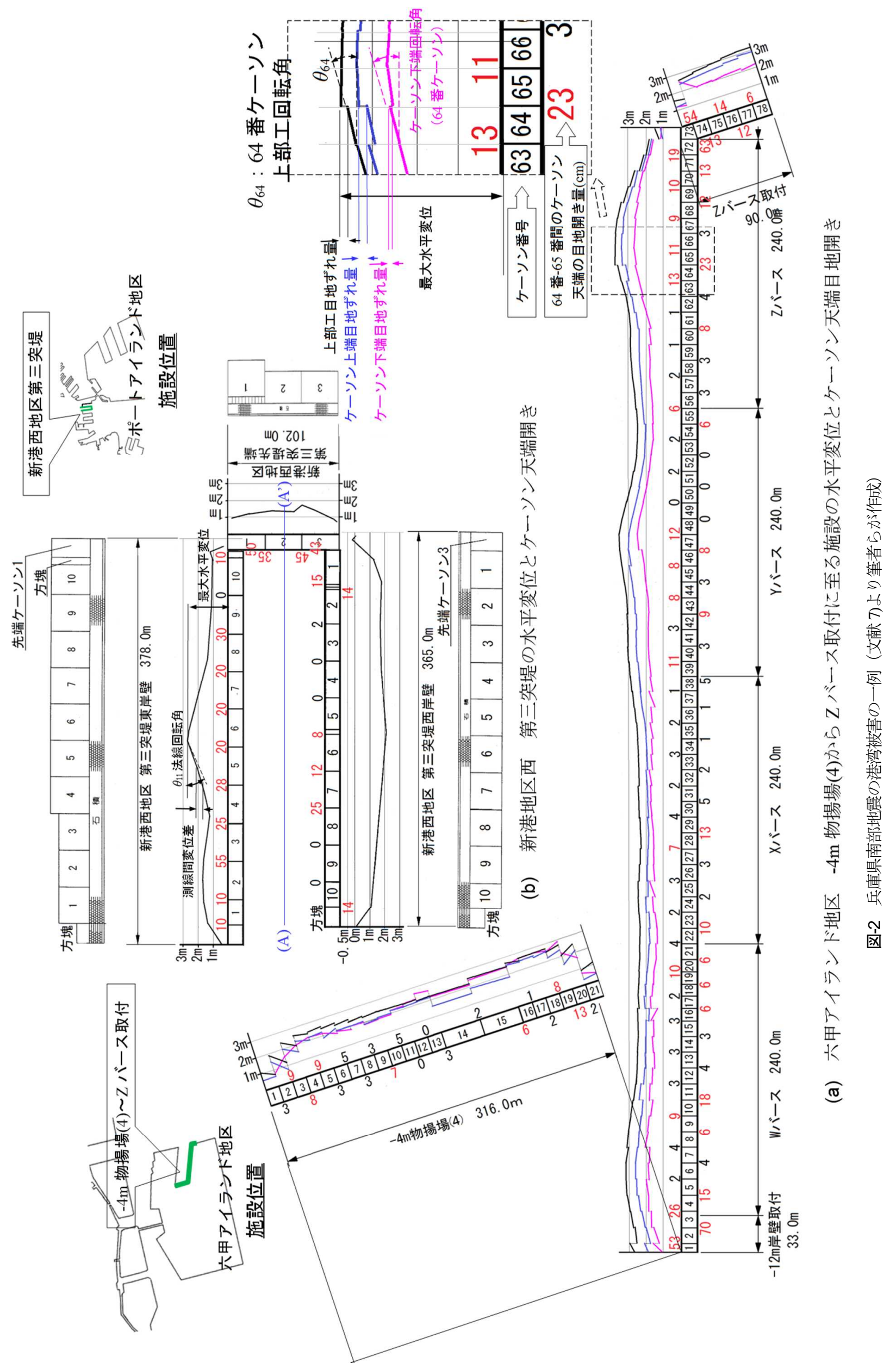


上回るケーソン天端目地開きは赤色の数值としている. また，後に記載する目地ずれ量とケーソン上部工回転角 について例示している.

図-2(b)には，神戸港新港西地区第三突堤の断面方向の 水平変位量とケーソン上端の目地間隔の概略図を示寸.

図-2(a)と同様に，突堤を構成する3施設の法線出入りと 目地開きが別々の図として示されていたものを，筆者ら がつなぎ合わせて一つの図にまとめたものである. 図2(b)においては，ケーソン各函ごとの水平変位量は測定 されておらず，概ね $20 \mathrm{~m}$ 間隔に水平変位が測定されてい る.また，ケーソンの傾斜は測定されておらず，ケーソ ン下端の法線出入も計算されていない. 図-2(b)中の四角 枠いの中の数值がケーソン番号であって一連の施設が連 番となっている点は図-2(a)と同様である. 図-2(b)には, 後に記載する隣接測線間の変位差と法線回転角を例示し ている.

図-2(b)では，直接的に目地ずれ量が測量されていない ため, ケーソン毎に目地ずれが測量されている施設との 違いについて当時の被災調査を担当した関係者に聞き取 り調査を行った．関係者の話を総合すると，次の（ア） 〜（才）のような状況であったことがわかった. 測量用の仮法線からケーソンの出入については，できる 限り正確に測量を行った。（イ）20m間隔の測線で測量 したのは災害査定官の指示に従ったものである. しかしながら, 必ずしも20m間隔にこだわらず法線の変 化点やずれが発生している点はできる限り測量を行った.

（エ）ただし，水没に近い状態にあって測量そのものが 危険を伴う施設も多くあり，そのような施設では必ずし も施設の法線の変化点を十分に押さえることが出来なか った.（才）（エ）のように測量に危険を伴う場合は測 量できた点から内挿して水平変位を算出した場合もあっ た.これらのことから，図-2(b)のように20m間隔の測線 で測量された施設には，様々な被災程度，様々な被災測 量の程度の施設が混在しているものと考えられる.

\section{a) 施設の隅角部における断面方向水平変位の抑制}

図-2(a)を見ると，-4m物揚場とWバースの隅角部およ びZバースとZバース取付の隅角部のように，隅角部で はケーソンの水平変位が小さい傾向がある，また，被災 後の施設の法線は，緩やかに蛇行しているように見える。 - $4 \mathrm{~m}$ 物揚場(4)とWバースの隅角部に関しては，両方の施 設がそれぞれ海側へ変位しようとして，互いに競り合う ことで水平変位が抑制されたものと考えられる.Zバー スとZバース取付の隅角部に関しては，隅角部ケーソン が異形函であることに加え，両隣のケーソンの影響で隅 角部ケーソンへの作用土圧が小さく, 水平変位量が小さ くなったものと考えられる.

図-2(b)においても，施設両端付近の水平変位は施設の 中央付近と比較すると小さく, 被災後の施設法線は蛇行
している.

図-2に見られる隅角部において断面方向の水平変位が 小さくなる傾向は，比較的多くの施設に見られ，これに 対応して, 隅角部ケーソンと隣接するケーソン間の目地 ずれ量は大きくなる傾向があった.

\section{b) 目地開きの発生箇所}

図-2(a)において，ケーソンの目地開きに着目すると, 施設の隅角端に近いほどケーソン上端の目地開きが大き く，目地開きが生じている箇所も多いことがわかる.こ れらは岸壁の法線方向の移動によって生じているものと 考えられる. 兵庫県南部地震においては, 岸壁や護岸の 水平方向変位の影響は $100 \mathrm{~m}$ 以上に及んでいることが指 摘12されている. 文献12)を受けて提案された護岸の水平 変位に対する研究13においても, 護岸の水平移動の埋め 立て地側への影響は概ね $200 \mathrm{~m}$ 程度で収まっているよう である.しかし，図-2(a)を見てわかるとおり，目地開き は隅角部から200m以上離れた中ほどの場所でも生じて いると考えられる.

図-2(a)のケーソン下端の法線出入りに注目すると，ケ 一ソン目地開きが発生している可能性の高い（赤色で表 示している）箇所が法線出入りが海側に凸になっている 箇所および凹となっている箇所の近傍で多いように見え る. 突堤間に位置している-4m物揚場(4)については，W 〜Zバースと比較して，目地開きが小さい傾向が伺える. 図-2(a)の-4m物揚場(4)の上部工法線出入およびケーソン 法線出入とケーソン下端出入を比較すると, 両端付近の ケーソン番号 $2,3,20$ において上部工（黒）およびケーソ ン天端の回転方向（青）とケーソン下端（マゼンタ）の 回転方向が逆向きであることがわかる. ケーソンが予め 抳れて作成されていたとは考え難いことから，ケーソン が垂直軸と回転軸として，水平方向に捻れるような変形 をしていることが示唆される.このようなケーソンの抳 れについて，ケーソンの左右を取り違えたプロットミス の可能性はある（文献10)のp.867 図-4.2.5.94 と p.870 図4.2.5.96の不整合）が，本研究では，先の証言 (ア）から このような調査結果が正しいものとして取り扱うことと した. 据れが大きいケーソンの上端及び上部工の回転方 向は隣接するケーソンと同じ方向であることが多いこと

（例えば，図-2(a) -4m物揚場の2番ケーソンとその両側, 20番ケーソンとその両側）から，筆者らはこの㧖れの要 因としてケーソン同士が接触することによるせり合いが あるものと考えている.

図-2(b)神戸港新港地区西第三突堤のケーソンの目地開 きでは，施設両端が特に大きいといった傾向は見当たら ず，施設の全延長で均等に発生しているように思われる. 図-2(b)にはケーソンの正面図のイメージを記載している が，東岸壁を見るとわかるように施設先端に行くほどケ ーソンの設置水深が深くなっている. 第三突堤の被災後 
の延長は文献10)には記載されていないが，施設全体が 先端方向に伸びるように変位したことによって施設全体 にほぼ均等な目地開きが発生したことが示唆される.

\section{c) 法線出入りの変化と目地開きに関する考察}

これまでに示した兵庫県南部地震港湾被害には以下の ような特徵があった。これらについて文献10)には明確 な表現は見当たらない.

・両端が隅角部であるような施設の両端の函塊は水平 変位が小さい傾向があり，隅角部ケーソンと隣接する ケーソン間の目地ずれ量も大きくなる傾向がある.

・施設の隅角端に近いほどケーソン上端の目地開きが 大きく，目地開きが生じている箇所が多い，しかしな がら，目地開きは隅角部から100〜200m以内でのみ生 じているわけでは無く, 施設延長の中程でも発生して いる.

・ケーソン目地開きが発生している可能性の高い（赤 色で表示している）箇所が法線出入りが海側に凸にな っている箇所および凹となっている箇所の近傍で多い ように見える.

・水深の深い方向に向かって設置された突堤において は，施設全体が先端方向に伸びるように変位したこと によって施設全体にほぼ均等な目地開きが発生したこ とが示唆される.

・ケーソンが水平方向に㧖れるように変形したことを 示唆する施設が存在する.

両端の水平変位が小さいことについて，海側に凸とな った隅角部と陸側に凹んだ隅角部では要因が異なってい ると筆者らは考えている，海側へ凸となった隅角函ケー ソンの陸側では（隣接するケーソンの影響で）土圧が作 用していない部分がある．更に，その先の施設の無い海 底においては，地盤の変位は更に小さいと考えられる。

これらの作用土圧の低下や3次元的な構造の変化による 水平変位の減少によって, 隅角部の施設端では水平変位 が抑制されているものと考えられる．陸側へ凹んだ隅角 部では，隣接する施設（図-2(a)の-12m岸壁取付では-4m 物揚場(4)）の存在によって隅角部の変位が抑制されて いると考えられる.これらのことから，隅角部付近で目 地ずれ量が大きいような傾向が見えるのは，これらの要 因で隅角部での水平変位が抑制されているためであると 考えられる.このような抑制が一つの要因となって, 隅 角部の近傍では, 目地ずれ量が大きくなる傾向があるも のと考えている. ただし，法線出入りの変化は，この2 つの要因だけでは無く, 埋立土を含む地盤の液状化の程 度の相違や施設断面の違いといった他の要因も加わって 生じていると考えている.

目地開きに関しては，二つの要因が関係していると筆 者らは考えている. 一つは, 地盤の液状化に伴って発生 する法線方向へ伸びるような施設の変形である. 筆者ら
は，図-2(a)の-12m岸壁ZバースとZバース取付の隅角部 で発生している目地開きが主としてこの要因によるもの と考えている.この要因については, 文献12)や文献13) で指摘されている側方流動的な変形であると考えられる. ここで，例えば図-2(b)に示した断面(A)-(A')で第三突堤先 端の水平変位を動的変形解析 ${ }^{3)}$ や流動化変形の計算 ${ }^{13)}$ で 求めることを考える. これらの研究で提案された手法は 2次元のFEM計算であるため, 断面(A)-(A')の解析には隅 角部の変位抑制効果は考慮できず，断面(A)-(A')の水平 変位は東西岸壁の法線延長方向の変位よりも大きめに計 算されると考えられる.したがって，このような解析を 実施することで, 各々の目地位置での(A)-(A')断面の海 側への水平変位量から目地開き量を大き目に想定するこ とが可能であると考えられる。

目地開きの二つ目の要因は, 函塊が垂直軸回りに回転 することによるものであると思われる，それを示唆する ものが，ケーソンの捩れ変形であると筆者らは考えてい る. 図-2(a)の-4m物揚場(4)の両端のケーソンの法線出入 りを見ると，ケーソン下端の出入りは，比較的滑らかな 変化をしているが, ケーソン上端と上部工の法線出入り は施設両端で鋸の歯のような形をしている. ケーソン下 端はケーソン下の地盤の海側への変位に概ね追従してい るのに対し，ケーソン上端及び上部工はケーソン同士の 接触による拘束を受けてケーソンが椖れるような変形を しているように見える.これは，隣接ケーソンによって， 何らかの拘束が発生した可能性を示唆しているものと筆 者らは考えている，一方，地盤の側方流動的な法線方向 に伸びる変形に伴う目地開きが発生すると，隣接ケーソ ンの拘束は弱くなる方向に向かうであろうから, 施設の 延長が伸びることによる目地開きによって，函塊の回転 角が大きくなる可能性も示唆される.このことから，ケ ーソンを剛体と仮定し，ケーソン同士が接触していると 仮定して，ケーソンの水平方向の回転角から目地開きを 推定する手法が成立する可能性があるものと思われる.

既往の研究結果8),13)や文献14),15)で紹介された設計法を 用いることで，施設の法線方向一の流動的変形は，大き 目の推定が可能であると考えられる，このことから，本 研究では, 函塊の水平面内での回転による目地開き量の 推定方法を研究対象とした.

先に述べたように, 兵庫県南部地震の神戸港の港湾被 害では，函塊の隅角部での隣接ケーソンによる土圧の軽 減を含んだ3次元的な断面変化, ケーソン相互や隣接す る施設の拘束効果, 液状化の程度の相違などが，目地ず れに影響を与えていることが示唆される，仮に，隣接 施設の存在によって, ある施設の水平変位が一定值に制 限されるとすると, 目地ずれ量はその施設の最大水平変 位が大きいほじ大きくなる傾向があると考えられる．あ る施設に部分的に液状化を起こさない箇所があるとする 
と，その施設の他の部分の液状化の程度が大きいほど

（言い換えれば，その施設の最大水平変位が大きいほど） 目地ずれ量は大きくなる傾向があると考えられる. 寸る と, 目地ずれ量は施設の最大水平変位と関係がありそう に思える. また，函塊の水平方向の回転角度も地盤の拘 束や3次元的な断面変化による法線出入りに影響される と考えられる. また，置換砂の液状化の程度が大きくな るほど，ケーソン下方の地盤の剛性が低下して，水平方 向に回転しやすくなることも考えられる．これらのこと から，函塊の水平方向の回転角度もその施設の最大水平 変位と関係付けられるように思われる，ただし，法線方 向へ施設が伸びるような変形で生じる目地開きとの関係 については，目地が開くことよって拘束が弱くなって函 塊が水平方向に回転し易くなるとも考えられるし，拘束 が弱くなることで回転角が小さくなるとも考えられる. このような考察のもとに, 次節では, 施設の最大水平変 位と目地ずれ量および目地開き量の関係を検討し，照 查基準の提案を行う.

\section{（3）照査基準の提案}

\section{a) 目地ずれ量の推定方法と照査基準}

第1章(2)節の図-1で考察したように，重力式の護岸構 造物の天端の水平変位が天端の壁体幅よりも小さければ, 写真-1(a)のような状態は生じず，施設としての天端高さ には欠損が生じないで高さが維持されるものと考えられ る. そこで，文献10)より，重力式函塊の両側の水平変 位が数值で記録されているものについて施設ごとの最大 法線出入りと函塊間の最大目地ずれ量を調査した. 図2(a)のように個々の函塊の地震前の施設法線からの出入 りが調查されている施設を模式的に表寸と図-3のように なる. 図-3のような調査をした施設の最大水平変位 $d_{\text {max }}$ とケーソン間の最大目地ずれ量 $e_{\max }$ の関係を施設毎にプ ロットしたものが図-4である，ただし，本研究が延長の 長い海岸保全施設を対象としていることから延長が 100mに満たない施設については除外した，また，図-2に 示したような隅角端の函塊であって隣接する函塊の影響 で法線出入りが抑制されていると考えられるものについ ても除外している. 図-4では施設の健全度との関係を見 るために施設が倒壊していたり水没状態にあった施設は 赤色で着色して表示している. ここで，結果的に図-4の 施設は全てケーソン式施設であった.

図-4の施設が全てケーソン式の構造物であったことか ら，水平変位が函塊ごとでは無く，図-2(b)のように概ね $20 \mathrm{~m}$ 毎の測線で表示されている施設についても施設の最 大水平変位と隣接測線間の最大水平変位差を調査した.

図-4を見ると，「崩壊も水没もしていない施設」と「一 部が崩壊または水没した施設」の最大変位と最大目地ず れ量の関係に大きな違いがあるようには見えない，図-4
では, 最大水平変位と最大目地ずれ量の関係として図中 に直線で示した概ね2:1 $\left(e_{\max }=0.5 d_{\max }\right)$ を見込んでいれば 安全側だと思われる.

図-2(b)のような調查をした施設を模式的に表すと図-4 のとおりとなる. 最大水平変位 $d_{\text {max }}$ と測線間の変位差の 最大值 $e_{\max }$ の関係を施設毎にプロットしたものが図-6で ある. 図-6にはL型ブロックに近い構造や方塊ブロック 積み構造の断面も含まれている. 図-4と同様に一部が倒 壊または水没した施設は赤色に着色している.さらに， 図-4で施設の最大水平変位と最大目地ずれ量の関係とし て提示した2:1 $\left(e_{\max }=0.5 d_{\max }\right)$ の線も書き加えている.

ここで, 先の（エ）のようにいくらか不正確な結果も 含まれているかもしれない状況も考慮すると, 図-6の測 線間の最大変位差を「状況が少し異なれば，目地ずれを 起こした可能性のある值」であると安全側の解釈するこ とも可能であると考えられる. 図中の $2: 1 の$ 線よりも上 側に位置する点の多くが「一部が崩塊または水没した施 設」であること，「崩壊も水没もしていない施設」で 2:1の線を明確に上回るものが図-6中で青い破線の円で囲 った1点のみであること」がわかる。この施設は高さ $1.21 \mathrm{~m}$, 幅 $1.82 \mathrm{~m}$ と $1.52 \mathrm{~m}$ の方塊を 2 段に積み重祊, その上 に場所打ちコンクリートを打設した構造である. 方塊の 法線方向の長さは不明であるが，方塊の幅から推測する と数mであると思われる. このことから，この施設につ いては方塊の長さに比べて測線間隔の $20 \mathrm{~m}$ が大きすぎた 可能性があると考えられる.ここで，この施設の被災状 況には, 水没・倒壊などの記載は無く, 被災写真にもそ のような状況は見られない. しかし, 被災状況断面図を 見ると, 被災後の天端高さがH.W.L.より下にあり, 水没 に近い状態であったと考えられる．これらのことから， この施設については例外的に取り扱うことができる可能 性がある.したがって, 図-6からも, 隅角端部を除いた 重力式港湾施設にあって崩壊も水没もしていない施設に ついては, 最大水平変位のおおよそ $1 / 2$ を最大目地ずれ 量であると想定してよいものと考えられる. ただし，一 部が崩壊又は水没した施設が，2:1の線の下側にも存在 していることから，施設の崩塊や水没の可能性が小さい ことについては十分に確認しておくことが必要であると 考えられる. また, 2次元有効応力解析などで施設が倒 壊や水没しないと確認されたとしても, 照査基準を適用 する最大水平変位に制限を設けておくことも必要である と考えられる. 図-6では, 施設の最大水平変位 $1 \mathrm{~m}$ 越 えたところで「一部が崩壊または水没した施設」が現わ れている. 最大水平変位が概水 $1.5 \mathrm{~m}$ 上回ると, 「一部 が崩壊または水没した施設」に最大水平変位と測線間変 位差がほぼ同じとなる施設が現われている，また，最大 水平変位 $2 \mathrm{~m}$ では例外かもしれない1施設が現われる. こ のことから，その制限值としては， $1.5 \mathrm{~m}$ 程度が適切であ 


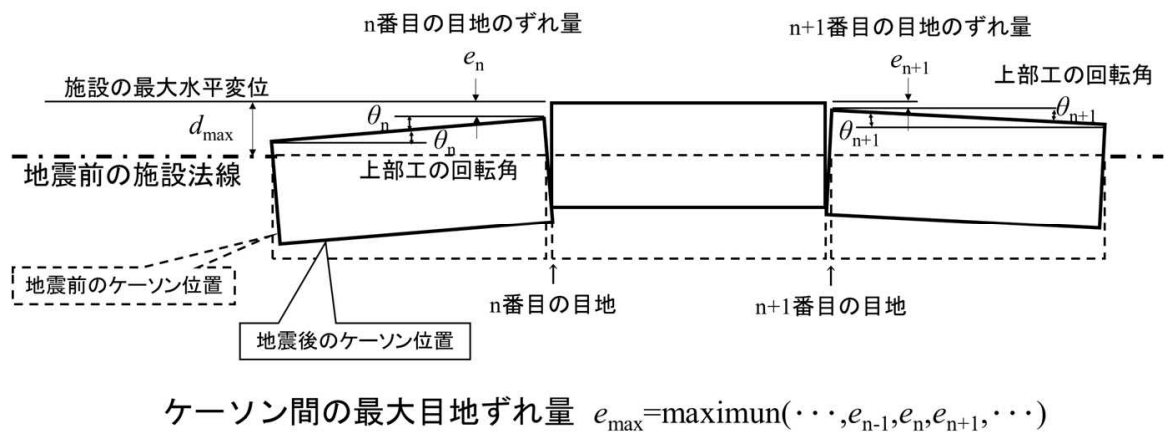

図-3 個々のケーソンの水平変位が計測されている施設の模式図

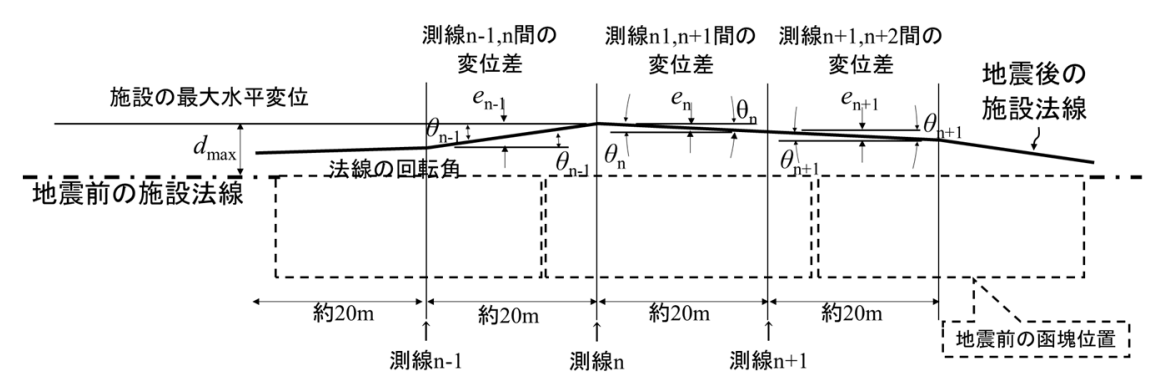

隣接測線間の変位差の最大值 $e_{\max }=\operatorname{maximun}\left(\cdots, e_{\mathrm{n}-1}, e_{\mathrm{n}}, e_{\mathrm{n}+1}, \cdots\right)$

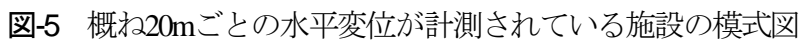
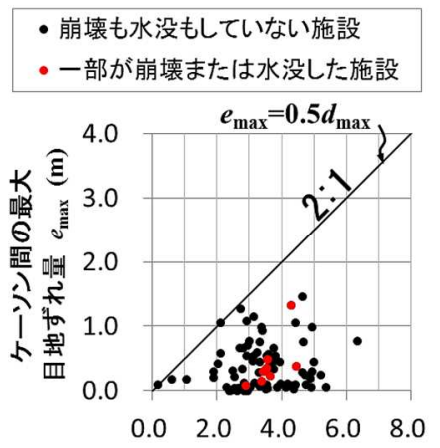

施設の最大水平変位 $\boldsymbol{d}_{\text {max }}(\mathrm{m})$

図-4 施設毎の最大水平変位量と 最大目地ずれ量の関係

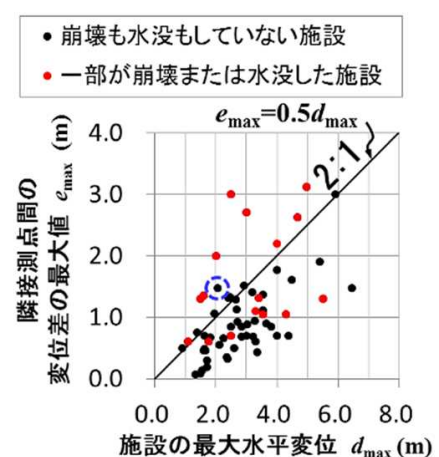

図6 施設毎の最大水平変位量と 隣接測線間最大変位差の関係

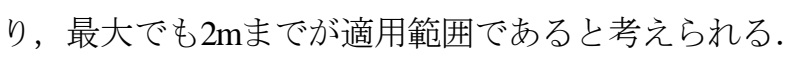
しかし，この照査基準をどの程度の最大水平変位にまで 適用するかは，最終的には事業実施者の判断になるもの と考えられる.

一方，ここで整理した施設の水位変位は施設の傾斜も 含まれた值であることから，照査基準の適用限界を明ら かにする点からも護岸の傾斜角の制限值を導入すること が必要であると考えられる. 図-4にプロットした89の施 設のうち，施設の傾斜角が測定されているのは44施設で あり最大の傾斜角は約 $6.8^{\circ}$ であった. このことから， 図-4は概ね傾斜角 $7^{\circ}$ 程度まで適用できると考えられる。 一方，図-6の60施設においては，傾斜角が測定されてい る施設は5つであって最大傾斜角は約 $13^{\circ}$ であった。 う ち1施設は部分的に水没していた。このことから，図-6 の施設の傾斜角から適用限界を設定することは困難であ ると考えられる。 ただ，図-6の1:2の直線は，水没・倒壊 していない施設を対象にしたものであることから，施設 の被害程度に相当する傾斜角を照査基準とすることがで きると考えられる. 小泉ら ${ }^{10}$ は, 日本海中部地震, 釧路 沖地震, 北海道南西沖地震, 三陸はるか沖地震, 兵庫県 南部地震の港湾施設の被害と港湾施設の被害程度17)を比 較し，応急復旧で暫定利用が可能となる被災程度はIか らIまでと評価している. 被災程度川の港湾施設の傾斜

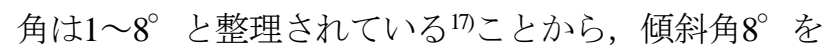
護岸の傾斜に対する照査基準として準用する考え方も成 立すると考えられる.
これらのことから，根入れの無い重力式護岸の設計津 波に先行する地震に対する照査基準として, 次のとおり 提案する.

・海岸護岸の設計地震に対する残留水平変位量を護岸天 端幅 $w の 2$ 倍以下とする.

・照査基準を適用する施設の残留水平変位量を概ね $21.5 \mathrm{~m}$ 程度以下とする.

・護岸の傾斜角が $8^{\circ}$ 以下であること

・護岸の変形モードが倒壊したり, すべり破壊を起こす ようなものにならないこと.

\section{b) 目地開き量の推定方法と照査基準}

前節で示したように海岸護岸の変形をある程度許容す るような照査基準を適用する際には，断面方向のみなら ず法線方向の変形も伴うと考えられる.このことから, 写真-1(b)に見られるような目地開きに関して目地からの 浸水量の照査を行い, 浸水量が多いと想定される場合に は浸水対策を行うことが望ましいと考えられる，そこで， 本節では目地開きの推定方法と照査規準を提案する.

\section{- 目地開き量の推定}

図-2に見られる隅角端部近くに多く発生している目地 開きは施設の延長方向への変形によって生じているもの と考えられる. 図-2(b)のように突堤の延長全域に生じて いる目地開きも突堤の先端方向に向から流動的な変位に よって生じているものと考えられる.このことから，例 えば文献3), 13), 14), 15)で紹介されている方法などで施設 
延長方向への移動量が推定できれば，目地開き量の想定 が可能であると考えられる. しかし，図-2(a)のW〜Zバ 一スの中程（ケーソン番号8～66）に生じている目地開 きについては，このような方法て推定することは難しい と思われる．このことから，比較的簡単な手法でW〜Z バースのような延長の長い施設の中程の目地開きを推定 できれば，本研究で示す海岸構造物の変形をある程度許 容した照査基準の検討の助けになるものと考えられる.

目地開き量が想定できれば，目地開きからの浸水量の想 定をすることが出来る. 寸ると, 本研究の照査基準を用 いた場合の浸水量を想定することが出来るとともに，排 水構造の設計などにも用いることができると考えられる からである.

目地開き量の想定に当っては，目地ずれ量と同様に施 設の最大水平変位と関連付けられると便利である. 図2(a)において，ケーソンの変位が海側に凹凸である付近 で目地開きが生じている可能性が高いと見えること，お よび，ケーソン同士の接触や競り合いが生じていたと考 えられることから，函塊が回転することによる目地開き を考えた，例えば，図-7に示すように，単純にケーソン のような函塊2つが設置されている場合を考える．次に， 隣接寸る函塊2つが破線の初期状態から被災後に実線の ように回転を伴った水平移動をした場合を想定する。 こ のような単純な場合, 図中の赤字に示すように目地開き が生じると考えられる.このことから, 図-7のように単 純な函塊の水平回転と断面方向への水平移動によって, 実際の目地開き量のどの程度説明できるのかを検討して みた. その結果を幾つかの施設について, 図-8に示す. 文献10)では，ケーソンの水平変位として，上部工天端 法線出入, ケーソン天端法線出入, ケーソン下端出入が あり, 函塊の変形量としてどの值を用いるかが問題とな る.ここでは, フーチングがあるためケーソン底版部分 が最も幅が広く, 図-7に示すように隣接するケーソンが 接触するのはケーソン底版部分であると考えてケーソン の変位量としてはケーソン下端出入を用いた. ケーソン 間の目地開きについては，上部工天端，ケーソン天端， 堆積土砂表面といった箇所が記載されている施設がある. しかしながら，上部工目地開きは $100 \mathrm{~mm}$ 以上の值を示し たケーソン天端目地開きのみを記載したと思われる目地

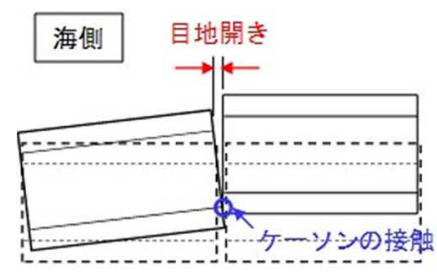

陸側

図-7 ケーソンの回転に伴う目地開きの模式図
が大多数であった. このことから，目地開き量にはこの ケーソン天端目地開きと堆積土砂上面目地開き量を記載 した。 ただし, 図-8の(a)(c)(d)の施設では, 堆積土砂上 面目地開き量が計測されていない. 加えて, 図-2におい てケーソンの㨭れ変形が見られることから，上部工とケ ーソンの水平方向の回転角の差をケーソン捩れ角として 第二軸に示した.

図-8では，実測值である○といを計算值である青色 の×と比較する. ただし，この計算ではケーソンの据れ は考慮していないことから，上部工のケーソンの捩れ角 である赤色の・との関係性も見る必要がある．図-8を全 体的に眺めてみると, 隅角端部に近いケーソンではケー ソンの目地間隔の実測值が大きくなる傾向が確認できる. 実測值と計算值の比較では, 計算值が大きく算出されて いる場合があり, その左右どちらかのケーソンではケー ソンの㧖れ角が大きい傾向がある.このことから，ケー ソンが水平方向に㧖れるような変形が生じており，その 結果，上部工の目地開きが抑制されている可能性がある ことがわかる. 図-8(a)のケーソン番号6〜8，19〜24，47 〜 48, 64〜68, (b)のケーソン番号 $16 \sim 18, \quad 23 \sim 28$ ， (c)の 2〜4, (d)の15，(e)の4〜5のように，目地開きの実測值が 大きくなっているところの近傍で計算值が大きくなって いるところが見られ，実測值で目地開きが大きな箇所か ら2〜3函離れたところで計算值が大きくなっているとこ ろも見られる.このような箇所について調い゙てみたとこ ろ，ケーソンの法線方向の傾きによって目地間隔の開い た位置がずれていると考えられる箇所が多くあった。 具 体的に例示寸ると, 図-2(a)六甲アイランド地区Zバース 64番ケーソンと65番ケーソンの間の目地である. 施設の 地震後の天端高さの測量結果を見ると，65番ケーソンが ほぼ水平に沈下しているのに対して，64番ケーソンが63 番ケーソン側に傾斜しながら沈下している．64番ケーソ ンと65番ケーソン間の目地開きが大きくなっている原因 は，64番ケーソンが63番ケーソン側に傾いていることに あると考えられる. 加えて, 同一方向の傾きが複数函連 続すれば，目地開きの箇所が複数函ずれて現われること も考えられる. また, 被災前のケーソンの目地間隔とこ こで設定したケーソンの設計目地間隔 $50 \mathrm{~mm} の$ 差は誤差 となっており, 計算値はある程度の幅（ケーソンの据付 誤差）を考慮して評価することが適切であろうと思われ る.このようなことから, ケーソンの回転角から目地開 きを大きめに推定できる可能性は残されているものと思 われる. 函塊一つ一つの水平変位が計測されているのは 全てケーソン式岸壁であって海岸護岸への適合性は必ず しも明らかではない. 海岸護岸への適合性の検証は今後 の課題であるが，安全側の想定を導入すれば，海岸護岸 にも適用できるものと考えた。そここで，図-4と図-6の施 設について施設の水平平面内の回転角を調べた. その結 
土木学会論文集A1 構造 地震工学), Vol. 73, No. 3, 604 621, 2017.

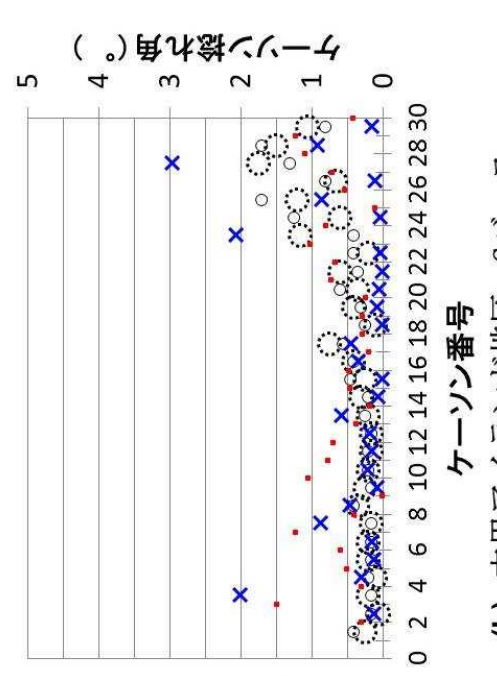

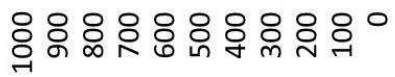

(um)曹呆嵌泒目

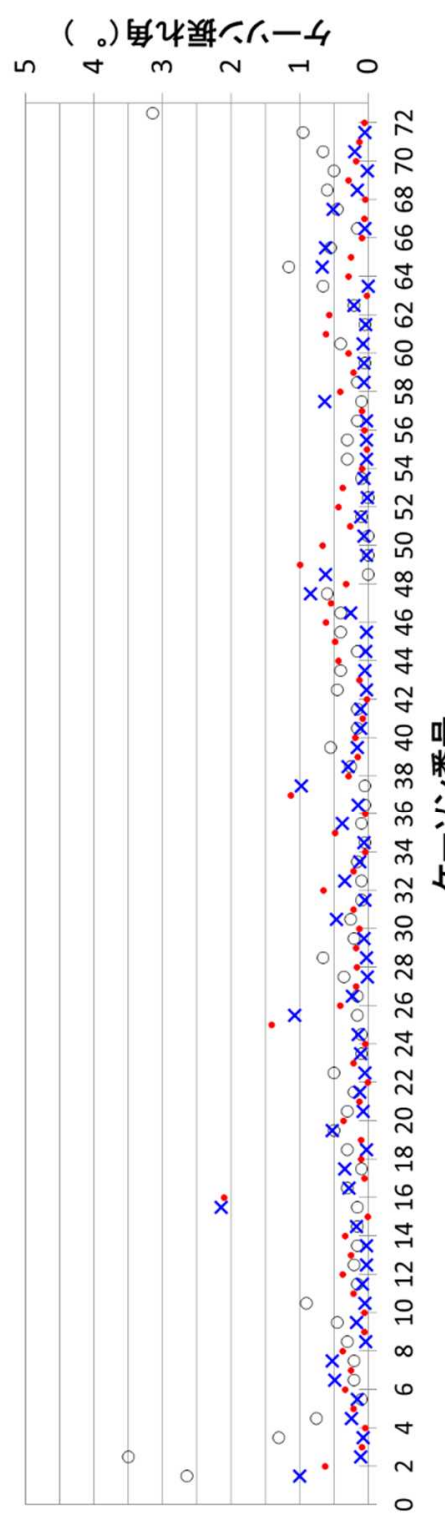

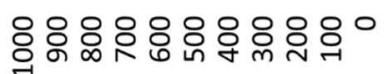

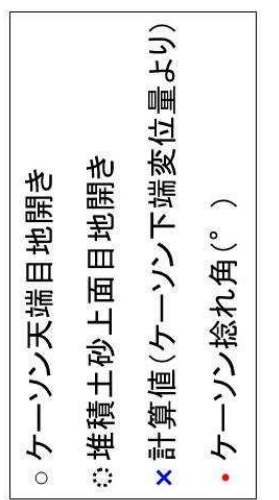

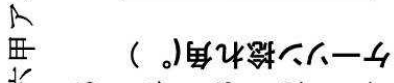

อิ

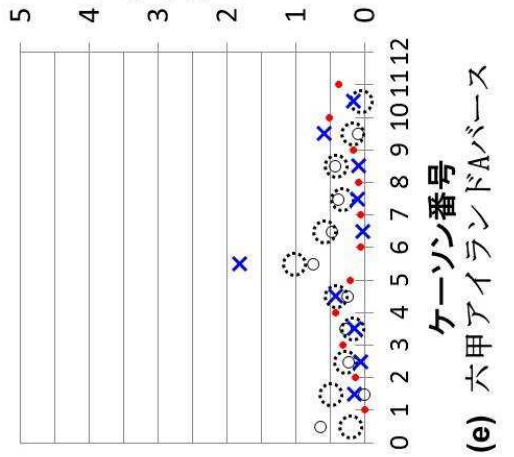

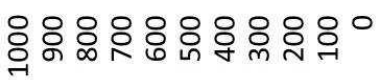

(um)曹早皆那目

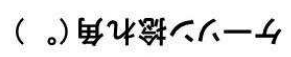

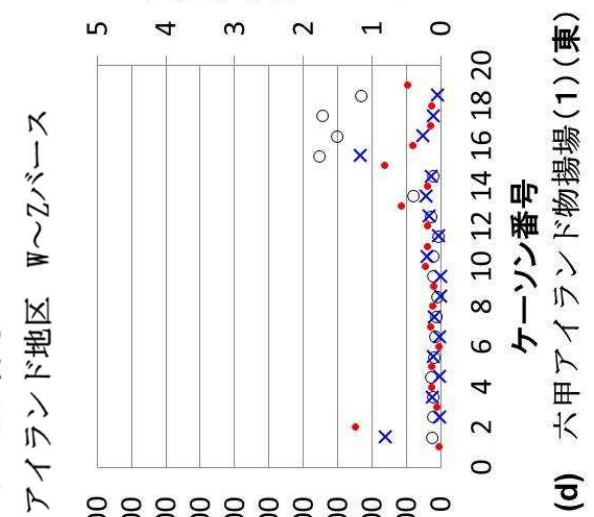

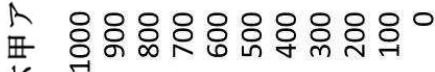

त

(um)霉虽炎船目

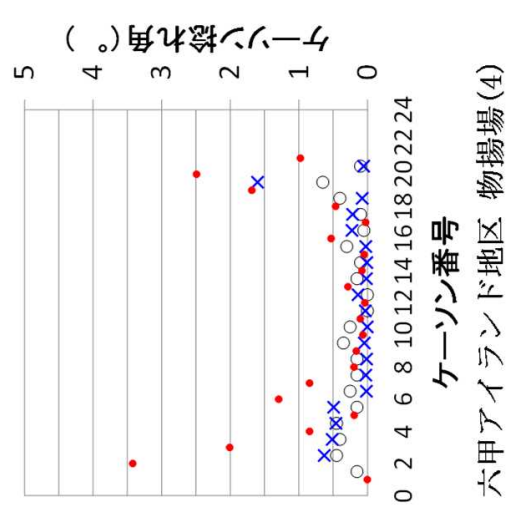

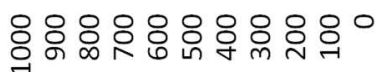

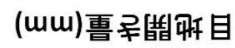

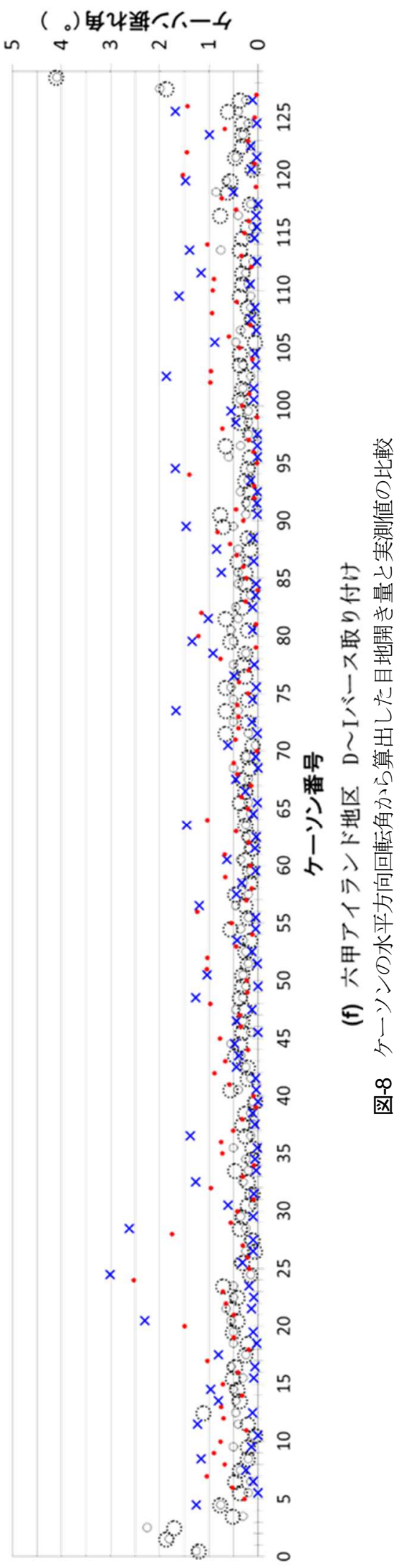

ए

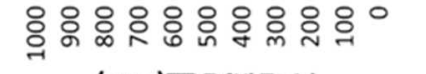


果を図-9に示す．ただし，図-4の施設においてケーソン の長さを特定できなかったものは除いている.

図-9(a)には，図-4の施設のケーソン毎の上部工の回転 角をプロットした．図-2(a)や図-3のようにケーソン各函 の水平変位が計測されている施設については，施設の最 大水平変位を横軸に，縦軸には図-3の $\theta$ で例示した上部 工の回転角を各函毎にプロットした．図-9(b)には，図-6 の施設について同様の法線の水平方向の回転角を整理し た. 横軸には施設の最大水平変位を, 綎軸には図-2(b)や 図-5の最大変位を横軸に，図中 $\theta$ で例示した測点間の回 転角を縦軸にプロットした。 したがって, 図-9(a)(b)とも に, 一つの最大変位に対して複数のプロットが存在する ここで，岸壁エプロンまでコンクリート舗装が施されて いる施設は，ケーソン下端の回転角に対して上部工の回 転角が小さい傾向が認められたため, 集計から外寸こと とした. さらに，ケーソンが極端なねじり変形を受けて いる図-2(a)の六甲アイランド地区- $4 \mathrm{~m}$ 物揚場(4)の $2 〜 4$, 19〜21番ケーソンも除外した. 同一の施設においても 個々のケーソンや測点間の回転角度のばらつきが大きい ため，図-9(a)では施設毎に回転角を単純平均したもの （ケーソン毎の上部工回転角平均值）を白色囲みの赤の 塗りつぶしで表現した. 同様に図-9(b)では白色囲み青色

(法線回転角平均值) で示している. ここで, どの目地 で目地開きが生じるかを特定することは非常に困難であ ると考えられることから, 目地からの浸水量を港湾の施 設の技術上の基準2の許容越波流量と同様に単位時間, 単位延長当たりの浸水量で照査しょうとすることを考え る. この場合, 平均的な目地開き量が得られた方が都合 がよい. 最大水平変位とケーソン及び法線の回転角は, 地盤条件の不均質性や地盤の液状化の度合い, 隣接施設 による拘束効果, 法線方向一の流動的な変形の影響など を受けているものと考えられる，筆者らは，このような 多くの影響を個別に把握し, 定量化する手法の開発まで には至っていない，また，このような場合，比較的簡単 な式である方が使用しやすい，一方，図-9のプロットは, 最大水平変位とケーソン及び法線の回転角の関係が, 上 に凸の関数形になることを予見させる．これらのことか ら，図-9には施設毎の最大水平変位と法線回転角の関係 を原点を通る2次曲線で回帰した式を示した。

ケーソンや施設法線の回転角は，図-2を見てもわかる とおり両端部で大きく，施設中央付近ではほとんど回転 していないケーソンもある.このことから，回転角はそ の間でばらつくものと想定される. 図-9(a)も(b)もこのよ ううな傾向が見て取れる. 図-9(a)では, 最大水平変位が $3.5 \mathrm{~m}$ までは水平変位が大きくなるに従って回転角が大き くなる傾向が見える. しかし, 最大水平変位が3.5mを越 えると回転角は小さくなる傾向が現われている. 図-9(b) では, 最大水平変位が大きくなるほど法線の回転角は大
きくなる傾向を示している. しかし，最大水平変位に対 する回転角の増分は最大水平変位が大きくなるほど小さ くなる傾向にある. しかしながら, 回転角の平均值を見 てみると, 平均的な值は最大水平変位との関係で表現で きそうにも思える. 図-9(a)と(b)を比較すると，(b)の方 が $\theta$ 值が大きい, このため目地開きの推定に用いる場 合は(b)の関係の方が適していると考えられる，そこで, 図-9(b)の式(1)によって施設法線の平均的な目地開きが推 定できるかどうか検討してみる.

$$
\theta=-0.0272 d_{\text {max }}{ }^{2}+0.4183 d_{\text {max }}
$$

ここで, 図-7をさらに単純化して図-10のように, 目 地ずれが生じず，片方の函塊のみが回転した状態を考え る. 図-10では, 上部工法線の位置にパラペット状の構 造が存在し, 津波・高潮に対寸る防護ラインを形成して いることを想定している. すると, 函塊の目地開きは単 純に式(2)で表すことができる.

$$
c=B \tan (\theta)
$$

式(1)と式(2)から，ケーソンの寸法が特定できた施設 について目地開きを推定した。 その結果を図-11に示す. 図-2に見られるように，隅角部，特に海側に凸となる隅 角部では隅角部周辺で目地開きが大きくなる傾向が見ら れることから，図-11には隅角ケーソンから4-5函間の目

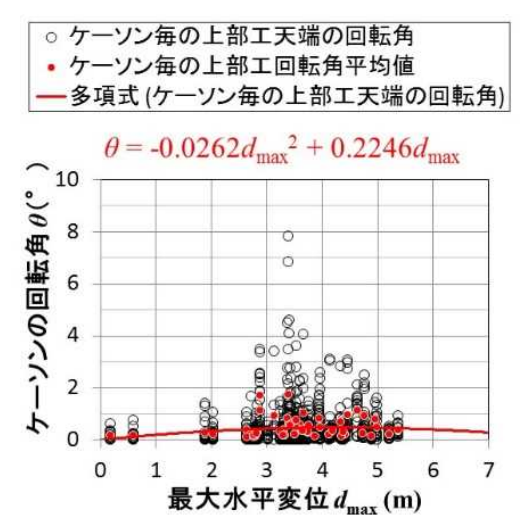

(a)最大水平変位とケーソン回転角の関係

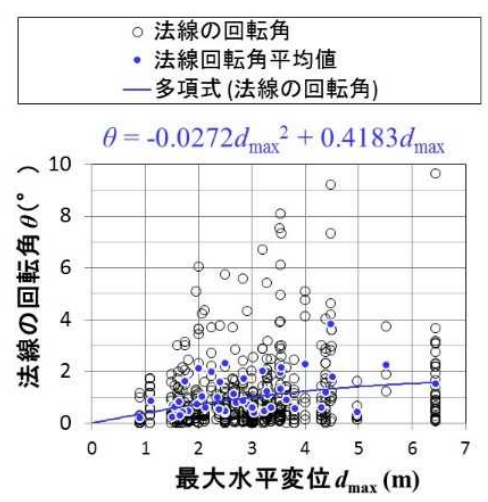

(b)最大水平変位と施設法線回転角の関係

図-9 施設毎の最大水平変位と法線・ケーソンの 回転角の関係 
地までの目地開き量を凡例のように赤色から深緑色に着 色して示した. 目地開きは数 $\mathrm{cm}$ から $1 \mathrm{~m}$ 以上に及ぶこと, および図の横幅を小さくするため, 横軸は対数軸とした. また，付録に図-11で示した施設の位置図を示寸.

図-11を見ると，凸隅角部に近い（着色した○）場所 での目地開きが大きい傾向が確認できる．また，凸隅角 部に近い着色した○を除いては, 概衩実測值を推計值が 上回る傾向が見られる．ただし，突堤式の施設について は，推定值が実測值を下回る傾向が見られる，ポートア イランド地区防波護岸（北側）（南側），中突堤地区岸 壁でも推定值が実測值よりも小さくなっている．付録の 施設位置図を参照すると，これらの施設は海側一張り出 した施設となっており，突堤と同じように施設が法線方 向に流動的に変位することで，大きめの目地開きが発生 することが考えられる.

これらのことから, 海側に張り出した隅角部に近い部 分及び突堤のような施設の目地開きの推定值とその他の 部分の目地開きの推定值を区分して比較してみた．その 結果を, 図-12に示す. 図-12(a)が海側に張り出した隅角 部から4-5函間の目地と突堤のように海側に突き出した 施設に対する推定值と実測值の比較である. 図-12(b)は, その他の目地に対する推定值と実測值の比較である. 図 -12(a)から，突堤等の施設と凸部隅角から5つ目の目地に 関しては, 妥当な推定が行えていないことがわかる.こ れは，「突堤等の施設と凸部隅角端から4-5函間の目地 については, 函塊の回転による目地開きよりも施設が

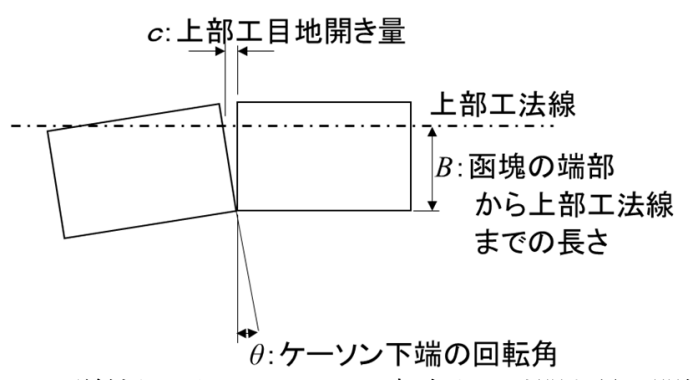

図-10 単純化したケーソンの回転角と目地開き量の関係
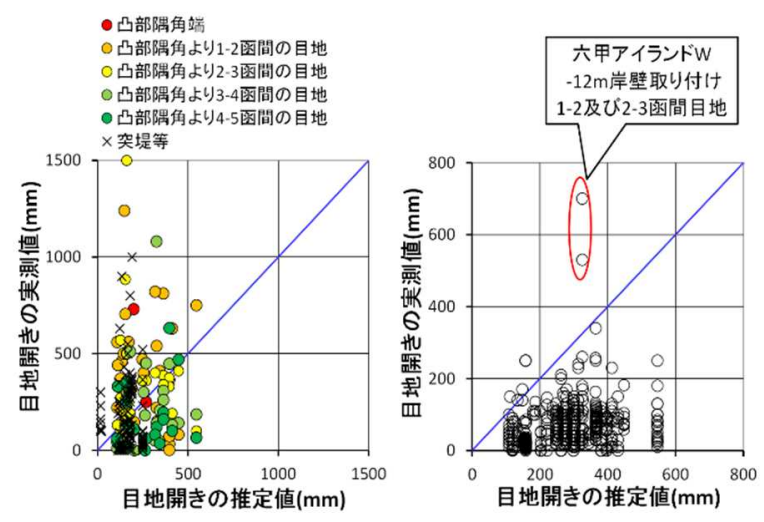

(a) 突堤 $・$ 凸部隅角端

(b) その他の目地

図-12 目地開きの推定結果
法線方向に伸びるような変位に対する目地開きが支配 的であること」を示唆していると思われる.これに対 して, 図-12(b)では, 図-2(a)で示した-12m岸壁取付のケ ーソン番号1-2間の目地及びケーソン番号2-3間の目地を

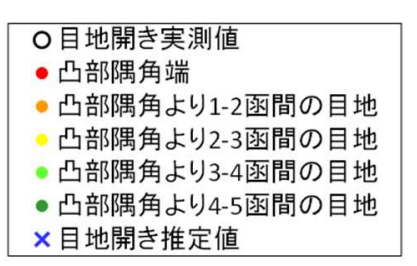

\section{目地開き $(\mathrm{mm})$}

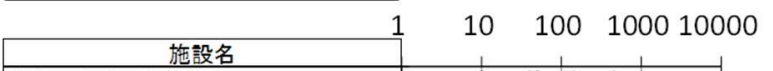

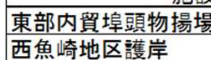

西魚崎地区卸影地区物掦場

六甲アイランド地区 RL-1

\begin{tabular}{ll} 
六甲アイランド地区 $\mathrm{RL}-2$ \\
\hline 六甲アイランド地区 $\mathrm{RL}-2$ (盛)
\end{tabular}

\begin{tabular}{l} 
六甲アイランド地区 RL \\
\hline 六甲アイランド RF-3
\end{tabular}

六甲アイランド地区 Wバース

六甲アイランド地区 Xパース

六甲アイランド地区 $Y$ バース

六甲アイランド地区 Zバース
六甲アイランド地区 Zバース取り付け

六甲アイランド地区 Dバース

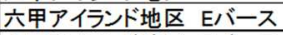

六甲アイランド地区 Fバース

六甲アイランド地区 $\mathrm{G} ハ$ バース

六甲アイランド地区 Hバース

六甲アイランド地区 Iバース
六甲アイランドIバース取り付け

六甲アイランド地区 $\mathrm{c}$ バース

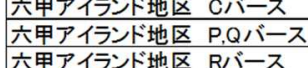

六甲アイランド地区 $R$ Rバース

六甲アイランド地区 Sバース

六甲アイランド地区 Tパース

六甲アイランド地区 Uバース

\begin{tabular}{l} 
六甲アイランド地区 Vバース \\
\hline 六甲アイランド地区 Aバース
\end{tabular}

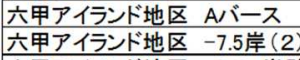

六甲アイランド地区 $-7.5 \mathrm{~m}$ 岸壁(3)

六甲アイランド地区 $\mathrm{N}, \mathrm{O}$ バース

六甲アイランド地区 物揚場 (1) (西)

六甲アイランド物揚場 (1)(南)

六甲アイランド物揚場 (1)(南)

六甲アイランド地区 物揚場 (1)

六甲アイランド地区 物揚場 (2)

摩耶埠頭地区 岸壁取り付け II

摩耶埠頭地区 岸壁(2)

摩耶埠頭岸壁

摩耶埠頭地区 物揚場

新港西地区 第二突堤西側

新港西地区 第二乫堤先端

新港西地区 第二突堤東側

新港西地区 第三突堤西側

新港西地区 第三突堤先端

新港西地区 第三突堤東側

新港西地区 第四突堤東側

新港西地区 第四突堤西側

新港東地区 第五突堤西側

新港東地区 旧貯木場東側物揚場

新港東地区旧貯木場北側物揚場

ポートアイランド地区 PC1 岸壁取り付け

ポートアイランド地区 PC10バース

ポートアイランド地区 物揚場その2(1/4)

ポートアイランド地区 物揚場その2(2/4)

ポートアイランド地区 物揚場その2(3/4)

\begin{tabular}{l} 
ポートアイランド地区 物揚場その2(4/4) \\
\hline ポートアイランド地区 護岸 (先端)
\end{tabular}

ポートアイランド地区 東護岸

ポートアイランド地区 物揚場その4

ポートアイランド地区防波護岸(北側)

ポートアイランド地区防波護岸(南側)

中突堤地区 岸壁 (1)

中突堤地区 岸壁 (1)

中突堤地区 岸壁 (1)

中突堤地区 岸壁(2)

須磨港 岸壁

図-11 函塊間目地開き量の推定結果

\begin{tabular}{lll|}
\hline & 0 & 0 \\
0 & $00 \mathrm{CONO}$
\end{tabular}

O 0

$\rightarrow x$

(1) 10000

C०0 0

0त् \&

$000000 \times$

C0 ब $x$

$000000 \times 0$

$00 \times 0$

(aimin $x$

- core $x$

다이 $x$

$0000 \times 0$

Qminoc

cos 0

$0 x$

- $\frac{\sigma x}{x}$

00000x

$00000 x$

$000000 \times$

$0000 \times 0$

(conos

OCID $0 x$

00000

000 (ain) $\times \infty 0$

arescos $\times$

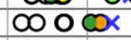

$\infty 000$

00000

- $\times 100$

काin

0 0xo

$\infty \mathrm{c}$

$\times 0$

$0 \times 0$

$0 \times$

$0 \times 0$

$\times 0$

000

0

(1)

X

DIO
$x \quad 0$ $\times 0$ 0

20000 x $x$ 
除いては，やや大きめに目地開きを推定できていること がわかる. このことから，隅角部や突堤のように海側に 張り出した施設に対する課題は残るものの, 兵庫県南部 地震の港湾被害のうち延長の長い施設の中ほどの平均的 な目地開き量は, 式(1)と式(2)を用いて大きめに推定で きるものと考えられる．しかしながら，先に述べたよう に, 突堤のように海側に張り出した構造の目地開きを推 定する場合は，施設法線が海側へ延びるような変形を解 析して予測する必要があると考えられる.

こうして推定した目地開きに対する性能規定としては, 護岸が津波の作用に耐えられることを前提として「津波 による目地開きからの浸水量が許容できる程度に小さい こと」あるいは「津波よる目地開きからの浸水量が次の 津波までの間に排水できること」等が考えられる．津波 に対寸る目地からの浸水量についての具体的な照査基準 としては，例えば，港湾の施設の技術上の基準2にある 許容越波量の規定值を目安とすることが考えられる.

このように定めた照査基準を満足しなければ，目地か らの浸水防止策や侵入した津波の排水措置を講じる必要 も生じるものと考えられる.

\section{4. 照査基準を用いた設計フローの提案と設計例}

\section{(1) 対象事業の概要および事業目的}

第3章で考察した照査基準が実務的に適用可能である かどうかを，実際の海岸保全施設整備事業に適用した事 例を示す．本研究で照査基準の検証に用いる事業は，撫 養港直轄海岸保全施設整備事業 ${ }^{18)}$ である. 事業の目的は 地震津波から護岸背後の市民を守ることであるが，改良 寸る護岸は1961年の第二室戸台風の高潮被害の発生を受 けて, 高潮対策として整備されたものであることから, 事業の目的は「海岸を整備することによって, 高潮や地 震津波が発生しても当該海岸背後地域の生活, 経済活動 に多大な支障を生じさせない.」と定義されている. 対 象事業は本研究で示した照査基準が最初に導入された海 岸事業である. 図-13に事業位置図を示す.

\section{(2) 設計条件}

\section{a) 設計地震}

対象事業（以下，単に「事業」と称する）の着手は平 成19年であったことから, 中央防災会議の東南海・南海 地震等に関する専門調査会が発表したもの ${ }^{199}$ を用いてい る. 設計地震動の作成は常時微動観測に基づいたゾーニ ングによって検討20)され，スペクトルインバージョンに よるサイト特性を用いて統計的グリーン関数法211で算定 している. したがって，中央防災会議が発表した地震動 波形そのものを用いているわけではない. 図-14に津波
に先行する地震動の一例として工学基盤における2E波

（護岸断面方向成分）を示す． $2 \mathrm{E}$ 波の最大加速度は約 $225 \mathrm{~cm} / \mathrm{s} / \mathrm{s}$ であ. また, この地震による初期地盤沈降量 は約 $0.7 \mathrm{~m}$ と推定されている.

\section{b) 設計津波}

設計津波の候補としては，次の 2 種類が選定された. 1 種類目は設計地震に伴って発生する津波である. 2 種類 目は1854年の安政南海地震津波の発生位置を当該海岸護 岸に最も危険になるように調整したものである。この2 種類の津波について, 文献22)で示されたような非線形 長波理論と線形長波理論の $2 つ の$ 基礎方程式を用いた津 波シミュレーションを行って比較したところ, 当該事業 区間における津波は，安政南海地震を調整した津波の方 が大きいことがわかった。これを受けて, 設計津波は安 政南海地震を調整したものとされた. このため, 設計地 震の震源と設計津波の波源は一致していない.

図-15には，後に設計例として示寸断面付近の津波高 さの時刻歴図を示す，津波高さの計算潮位はH.W.L.であ る. 津波の到達が地震発生後40分程度, 津波高さは C.D.L.+3.84m程度である. 他の地点の津波高さも考慮し て，この断面における設計津波高さをC.D.L. $+3.85 \mathrm{~m} と し$ た.

\section{(3) 護岸改良の設計例}

図-16に本研究で提案するコンクリート重力式護岸の 照査フローを示す.以下に，図-16のフローを用いた護 岸の改良例を示寸。

\section{a) 現況断面の耐震性評価}

図-16に既存の海岸護岸のうち最も大きな水平変位が 想定される工区の断面の一例を示す.この断面に対して, 既存海岸護岸の耐震性を評価するため, ひずみ空間にお

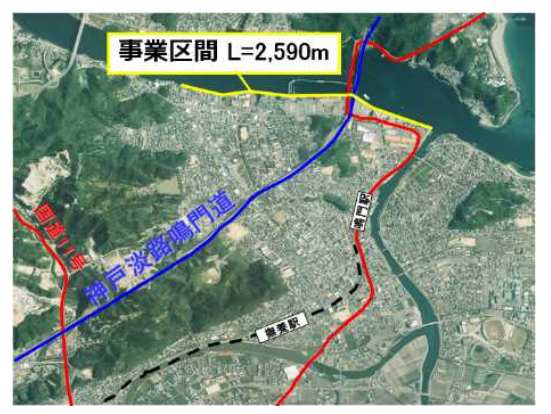

図-13 事業位置図（徳島県鳴門市撫養町）

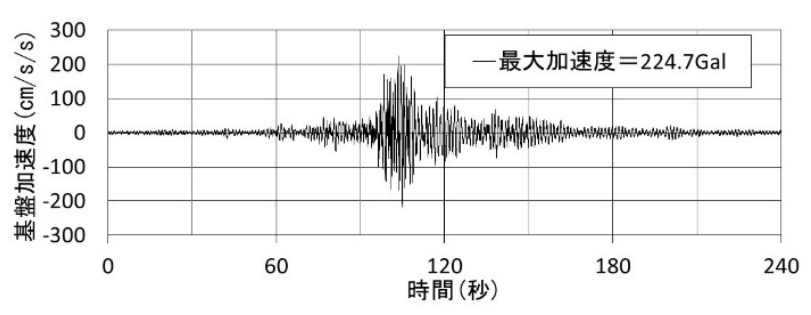

図-14 設計地震地震動の一例（工学基盤2E波） 


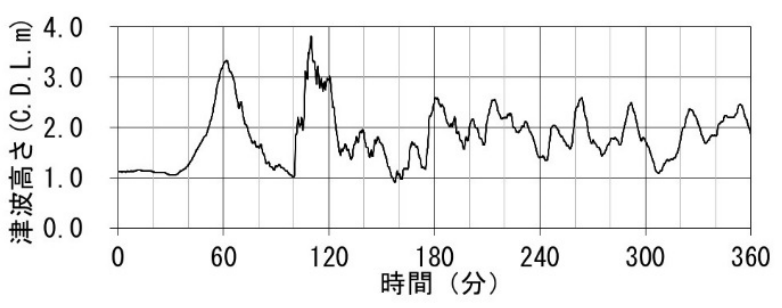

図-15 設計津波の時刻歴の一例

ける多重せん断ばねモデルを用いた動的変形形解析4)を 行った．解析にあたっては，有効応力の減少を塑性せん 断仕事に応じて算定するマルチスプリングモデルを使用 し, 非排水条件で解析している. 入力水平地震動は図14に示したものに加え，同様な手法で作製した鉛直動 を同時に作用させている．時間積分法等の解析条件は， 一般に用いられる標準的な方法231に準拠している. 図一 18に解析結果の一例として護岸の変形図を示寸．図中 のカラーコンタは過剩間隙水圧比である. 護岸の残留水 平変位は $2.80 \mathrm{~m}$ ，護岸天端の残留沈下量は0.37mであった。

護岸の天端高さは，図-18に示した通りC.D.L.+4.315m である. 初期地盤沈降量が約 $0.7 \mathrm{~m}$ ，地盤の液状化層厚が 約 $23 \mathrm{~m}$ 程度であることから液状化による排水沈下量を $3 \%$ 程度と見込んだ場合には $0.7 \mathrm{~m} の$ 沈下が想定される。した がって, 護岸天端は4.315-0.37-0.7-0.7=2.545m程度にな るものと想定される。図-15の最大津波高さが約 C.D.L.+3.84mであることから，護岸の天端高さを津波が 上回り，背後地域は浸水するものと考えられる．護岸の 水平変位量も2.80mであり, 写真-1(a)で示した西武1工区 護岸（長田西）に近い。このことから，護岸の目地ずれ も生じる可能性が高く, 護岸天端よりも低い津波に対し ても浸水が生じる可能性が高い，一方，護岸の傾きは 0.1 度であって, 変形モードも水平方向の変位が卓越し ており，倒壊の可能性は低い，以上のことから，当該護 岸は倒壊の可能性は低いものの, 設計地震によって護岸 としての機能を喪失するものと考えられる．当該護岸は 倒壊の可能性が低いことから，本論文で示した照査基準 が適用できるものと考えられる.

\section{b) 地盤改良の必要性の判断}

当該護岸の背後には，地表から $4 \sim 8 \mathrm{~m}$ の厚さで埋立土 の層が存在し，その下には沖積の砂質土層がC.D.L.-20 $27 \mathrm{~m}$ 程度まで存在する。埋立土層の $\mathrm{R}_{\mathrm{L} 20}$ は 0.2 程度, 沖積 砂質土層の $\mathrm{R}_{\mathrm{L} 20}$ が0.15〜0.35である．図-17を見ると，護 岸の直下の一部を除いてB層とAs1層が液状化しており, 兵庫県南部地震の港湾被害と同様に水平変位の主な原因 は埋立土層と沖積砂質地盤の液状化であると考えられ る.このことから，護岸の改良に当たっては地盤改良を 行うことが効果的であると判断された.

事業区間の前面海域は良好な漁場であり, 薬液注入工 法やセメント系の混合処理工法では漁業関係者の理解が

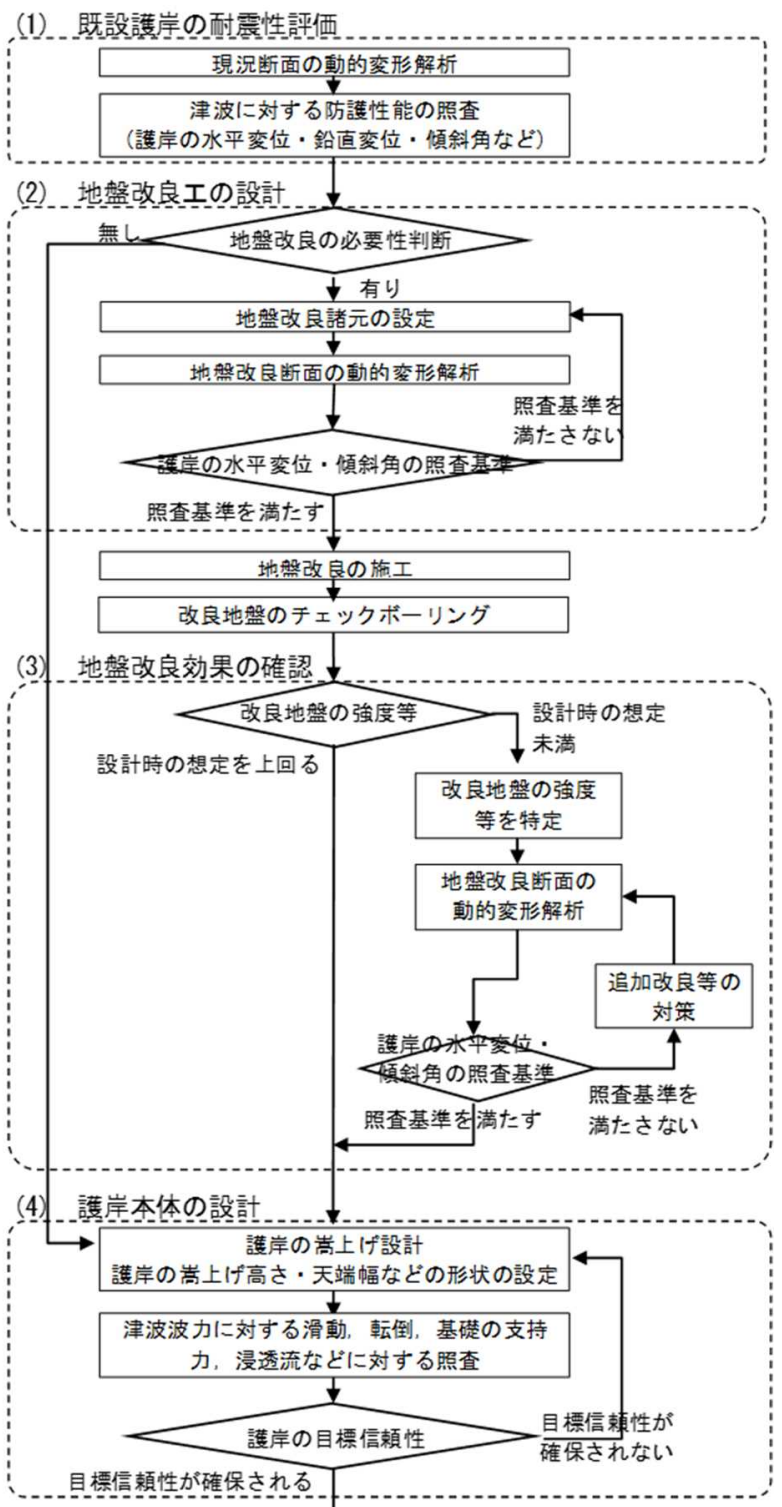

(5)_-_目地開きに対す_五照杗

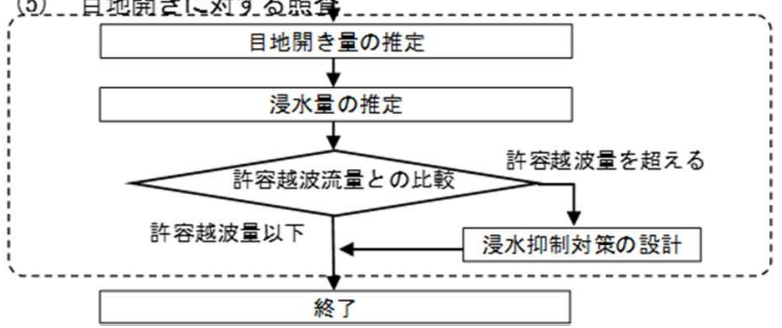

図-16 コンクリート重力式護岸の照査フロー

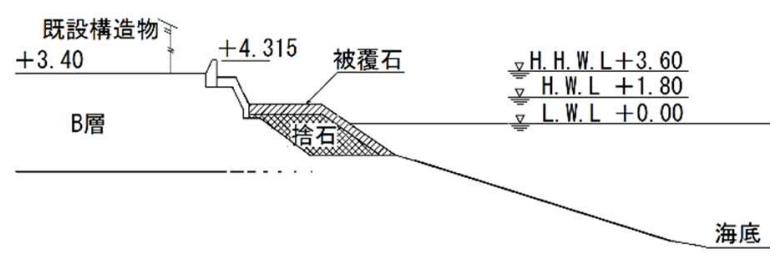

As1層

図-17 護岸の標準断面図

得られなかった. 一方, サンドコンパクションパイル工 法と低スランプのモルタルを圧入する静的圧入締固め工 


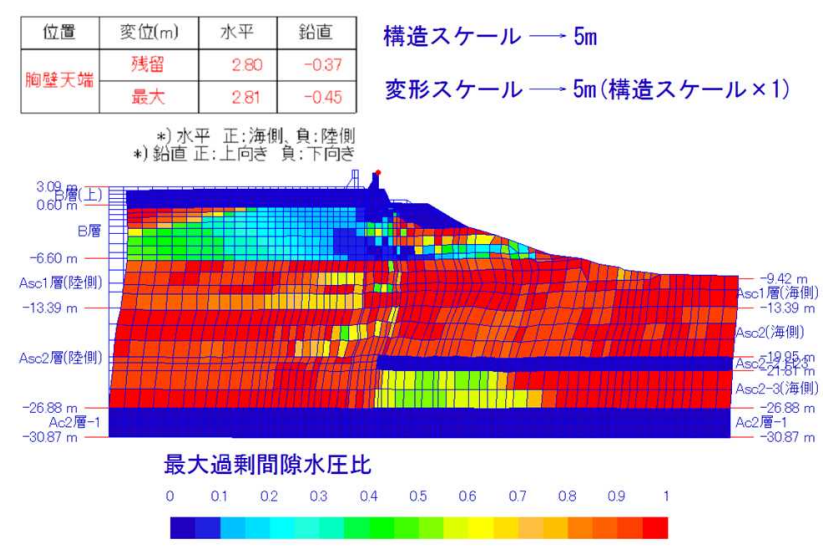

図-18 既存護岸の動的変形解析結果

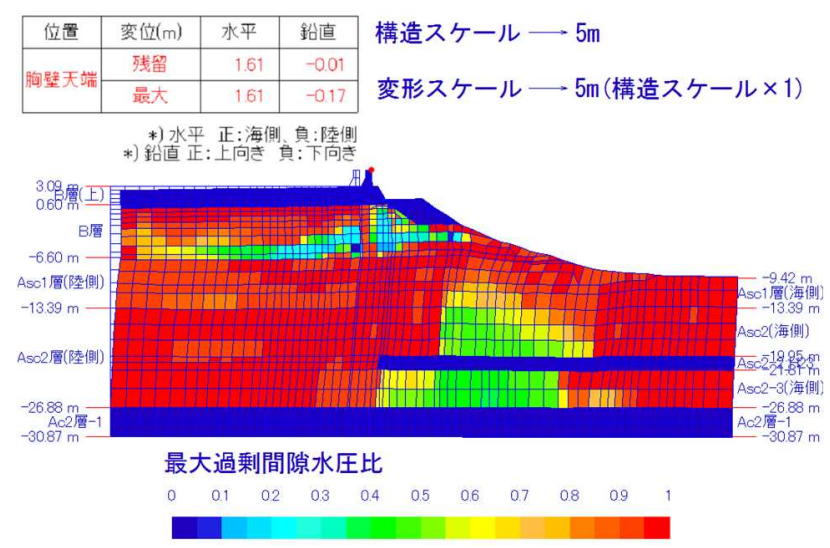

図-19 護岸の地盤改良断面の動的変形解析結果

法24は，漁業関係者の理解を得ることができた。しかし， 当該個所が第二種騒音規制区域であることからサンドコ パクションパイル工法は騒音を伴わない工法に限定され た. 海上からの静的サンドコンパクション25（以下，静 的SCP工法）と静的圧入締固め工法の経済比較を行った ところ, 海上からの静的SCP工法が安価となった。この ことから，海上から陸側に向かって施工できるところは 静的SCPで改良し, それよりも陸域部分は静的圧入締固 め工法を採用することとした．改良地盤の諸元は既往の 文献26)や技術マニュアル27などから設定した.

また，図-17の護岸の背後では，企業が事業を営んで おり, 事業主の建屋が存在する. このため, 護岸背後の 改良範囲は護岸直下までに限定された。 このことから， 地盤改良範囲を海側一延長させながら, 動的変形解析を 行って地盤改良範囲を決定することとした．本護岸の幅 は約 $0.75 \mathrm{~m}$ であり, 護岸幅と同じ幅で嵩上げすることを 想定すると, 護岸天端幅は0.75mとなる. したがって, 第3章2節b)項で提案した照査基準を適用すると，許容さ れる護岸の水平変位量は2倍の $1.5 \mathrm{~m}$ となる．これは図-6 から考えられる護岸の変形量の上限にも一致寸る.この ことから, 設計上の目標水平変位量を一先ず $1.5 \mathrm{~m}$ と設定 した．護岸の傾斜角の照査基準は $8^{\circ}$ とした．地盤改良 幅を変化させて繰り返し実施した動的変形解析の結果, 地盤改良幅は, 後の図-20に示寸とおりの $31.7 \mathrm{~m}$ となった。 c) 地盤改良効果の確認

所定の地盤改良を実施の後, 改良体の品質確認のため のチェックボーリングを行った. 当該断面のチェックボ ーリングでは，標準貫入試験と繰返し三軸圧縮試験（液 状化試験）を実施している，その結果，設計時の想定を やや下回っている層があった. 設計時の想定地盤改良強 度を下回った要因としては, 設計時に用いたボーリング では把握することができなかった細粒分60\%程度の土層 が狭在していた箇所があったこと，海底面に近い土層で は土被り圧が小さいために改良効果が表れにくかったこ との2点が考えられた。このことから, 再度, 改良地盤

の諸元を設定し，護岸の動的変形解析を行った．その 結果を図-19に示す.

図-19を見ると，護岸の前面のAs層で既存護岸よりも 液状化しない範囲が広がっており, 水平変位も $2.80 \mathrm{~m}$ か ら1.61mに抑制されている. 3.(2) b)で定めた水平変位に

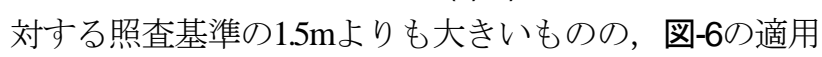
限界と思われる $2 \mathrm{~m}$ は下回っている. 護岸の傾きも $2.5^{\circ}$ と照査基準と比較して小さく, 変形モードも水平方向の 移動が卓越しており，滑りが生じているようには見えな い.これらを総合的に判断して, 護岸の水平変位は $1.5 \mathrm{~m}$ 程度であり，照査基準を満足していると判断した．ただ し, 護岸の水平変位がもっと大きかったり, 変形モード にすべり破壊のようなモードが現れた場合は追加の地盤 改良などを行う必要が生じるものと考えられる.

\section{d) 護岸本体の設計}

これまでの地盤改良の結果を受けて, 護岸本体の設計 を行った. 改良護岸に対し初期地盤沈降量 $0.7 \mathrm{~m}$, 護岸の 動的変形解析結果による護岸の残留鉛直变位は $0.01 \mathrm{~m} て ゙$ ある．地盤改良を施工しているが，安全側を考慮して液 状化に伴う排水沈下量 $0.7 \mathrm{~m}$ を加えると, 護岸は地震前の 状態から $1.41 \mathrm{~m}$ 沈下寸ることが想定される. これを図-6 の津波高さと比較すると，不足する護岸の天端高さは 0.945mとなる.このことから, 護岸の天端を $5.3 \mathrm{~m} に$ 嵩上 げすることとした，護岸の嵩上げ天端幅は，想定される 護岸の残留水平変位 $1.61 \mathrm{~m} の$ 約 $1 / 2 の 0.85 \mathrm{~m}$ に増厚すること とした．設計した嵩上げ断面図を図-20に示寸．図-20の 護岸本体に対して津波を波力を作用させて安定計算を行 った，その結果を表-1に示す，表-1より，改良護岸が津 波の作用に対して安定しており, 護岸の改良断面が設計 できたことがわかる，以上が図-20に示した断面の基本 設計の概要である. 現地の施工に当っては, 背後構造物 への地盤改良の影響を軽減するための仮設矢板の施工や 現場の条件に配慮した嵩上げ形状の変更などが行われた ため, 必ずしも図-20に示したとおりの断面となってい ない箇所があることを付記しておく. 


\section{e) 目地開きからの浸水に対する検討}

図-2(a)において示したように，延長の長い施設であっ ては施設の海側への隅角部を除く中ほどの区間にあって も目地開きが発生する.このことから，目地開きからど の程度の浸水が発生するか，あるいは，目地開きに対す る構造的な対処が必要か娝かを検討寸るために，目地開 きからの流入水量に対する検討を行った.

式(1)より，この護岸の最大水平変位1.61mに対する平 均的な法線の回転角度は $0.603^{\circ}$ となる. 次いで, 図-20 の嵩上げ断面において施設前端部より護岸前面の津波の 防護ラインまでの距離は図-20中に示したとおり $1.6 \mathrm{~m}$ ある．後端からの距離は1.3mである．施設前面からの $1.6 \mathrm{~m}$ に対して，式(1)と式(2)を用いて目地開き量を計算す ると $17.89 \mathrm{~mm}$ となる. したがって，この護岸では平均的 に18mmの目地開きが発生する可能性がある.

これを受けて，図-15の設計津波に対して，18mmの目 地開きが生じた場合の流量を水山ら ${ }^{28)}$ のスリット堰の公 式より計算した. ここで，水山らはスリットの幅が小さ くなった場合に流量係数が 0.4 程度まで小さくなること を指摘している28)が，酒谷ら ${ }^{29)}$ や塚本ら ${ }^{30}$ の研究結果を 受けて流量係数は 0.5 としてる. その結果を図-21に示 す. 1 目地 1 秒間当りの流入量は $0.065 \mathrm{~m}^{3}$ となった。仮に 函塊の目地間隔を $5 \mathrm{~m}$ とした場合, 護岸延長 $1 \mathrm{~m}$ 当りの流 入量は $0.0125 \mathrm{~m}^{3} / \mathrm{m} / \mathrm{sec}$ となる。 これは港湾の施設の技術上 の基準2にある「背後に人家，公共施設等が密集してお り，特に越波・しぶき等の進入により重大な被害が予想 される地区」の許容越波流量 $0.01 \mathrm{~m}^{3} / \mathrm{m} / \mathrm{sec}$ 程度を超えてい るが，「その他の重要な地区」の $0.02 \mathrm{~m} / \mathrm{m} / \mathrm{sec}$ 程度よりも 小さい.ささらに図-21から，津波1波当たりの浸水時間は 20分程度であることがわかる，河合らは，東京湾を例と

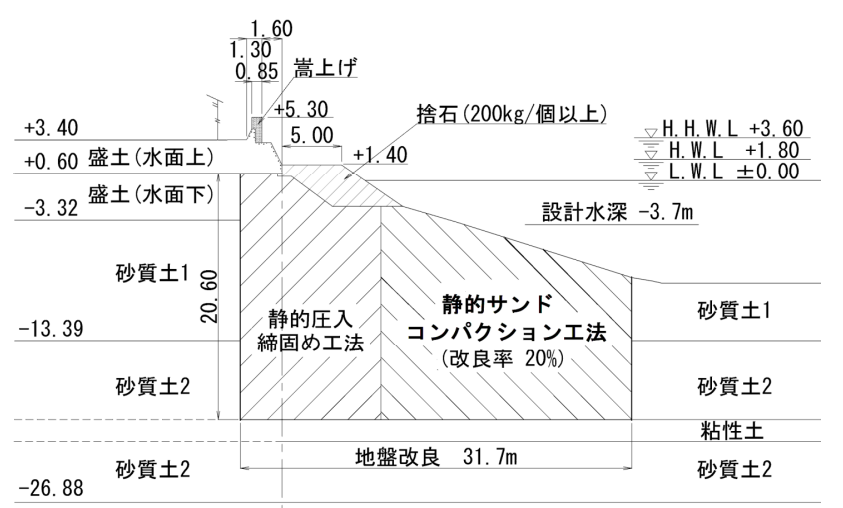

図-20 護岸の改良断面図

表-1 津波に対する護岸の安定性照查結果

\begin{tabular}{|c|c|c|}
\hline \multicolumn{2}{|c|}{ 滑動 } & $1.73>1.00$ \\
\hline \multicolumn{2}{|c|}{ 転倒 } & $2.38>1.10$ \\
\hline 支持力 & 偏心傾斜荷重対する耐力作用比 & $2.01>1.00$ \\
\hline 浸透力 & ボイリングに対する安全率 & 1.25 \\
\hline \multicolumn{2}{|c}{} \\
\hline \multicolumn{2}{|c|}{}
\end{tabular}

して，台風による高潮と高波の同時性を検討する中でモ デル台風による護岸の累計越波量を試算している311. こ れによると，高潮と高波のピーク時間差によって異なる ものの 2 時間程度は越波が生じている. 山口らは, 高波 の継続時間を気象庁の長期波浪観測資料から統計的に分 析している32．文献32)によれば，50年確率波浪に対する 平均継続時間は, 日本海側では約3.5時間, 太平洋側で も2.2 4. 時間と推計されている. これらの検討と比較 寸ると，津波による目地からの浸水時間は台風などの波 浪による越波の継続時間や高波浪の継続時間よりも小さ いものと考えられる.

これらのことから，図-21の事例については，目地開 きからの津波の浸水があったとしても，大きな被害に は至らないものと思われる。したがって, 図-20に示し た断面においては, 浸水流量の観点からは, 目地開き からの浸水抑制対策は必ずしも必要ないものと判断さ れる.ただし, 当該事業においては, 護岸の嵩上コン クリートの目地部には伸縮性を有する止水板を挟み込 んでいる. 水吒き部分の舗装についても，事情の許す 限り実施した。 これらのことから, 目地付近の浸水に よる洗掘については, 検討していない. 目地開きから の浸水流速による洗掘が発生することが想定される場 合は, 洗掘防止や浸水の抑制といった対応策が必要に なると考えられる.

\section{5. まとめ}

本研究では，1995年兵庫県南部地震の港湾被害を分析 し，長い延長を持つ海岸護岸の中間部分を対象として津 波に先行寸る設計地震の照査基準について考察し，四国 地方整備局が実施した海岸保全施設整備事業に適用した. その結果をまとめると次のとおりである.

・1995年兵庫県南部地震のコンクリート重力式の護岸 や岸壁の被害を調査したところ, 隅角部における変 位の抑制効果を受けない箇所については，施設の最 大水平変位量と函塊の最大目地ずれ量の関係は概ね 2:1であることがわかった。これを踏まえて，コンク リート重力式の海岸護岸の設計地震に対する残留変 形量を護岸天端幅の2倍とする照査基準を提案した.

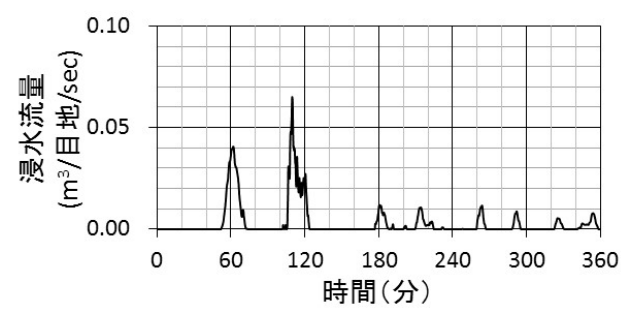

図-21 設計津波に対する目地1箇所当りの浸水流量 

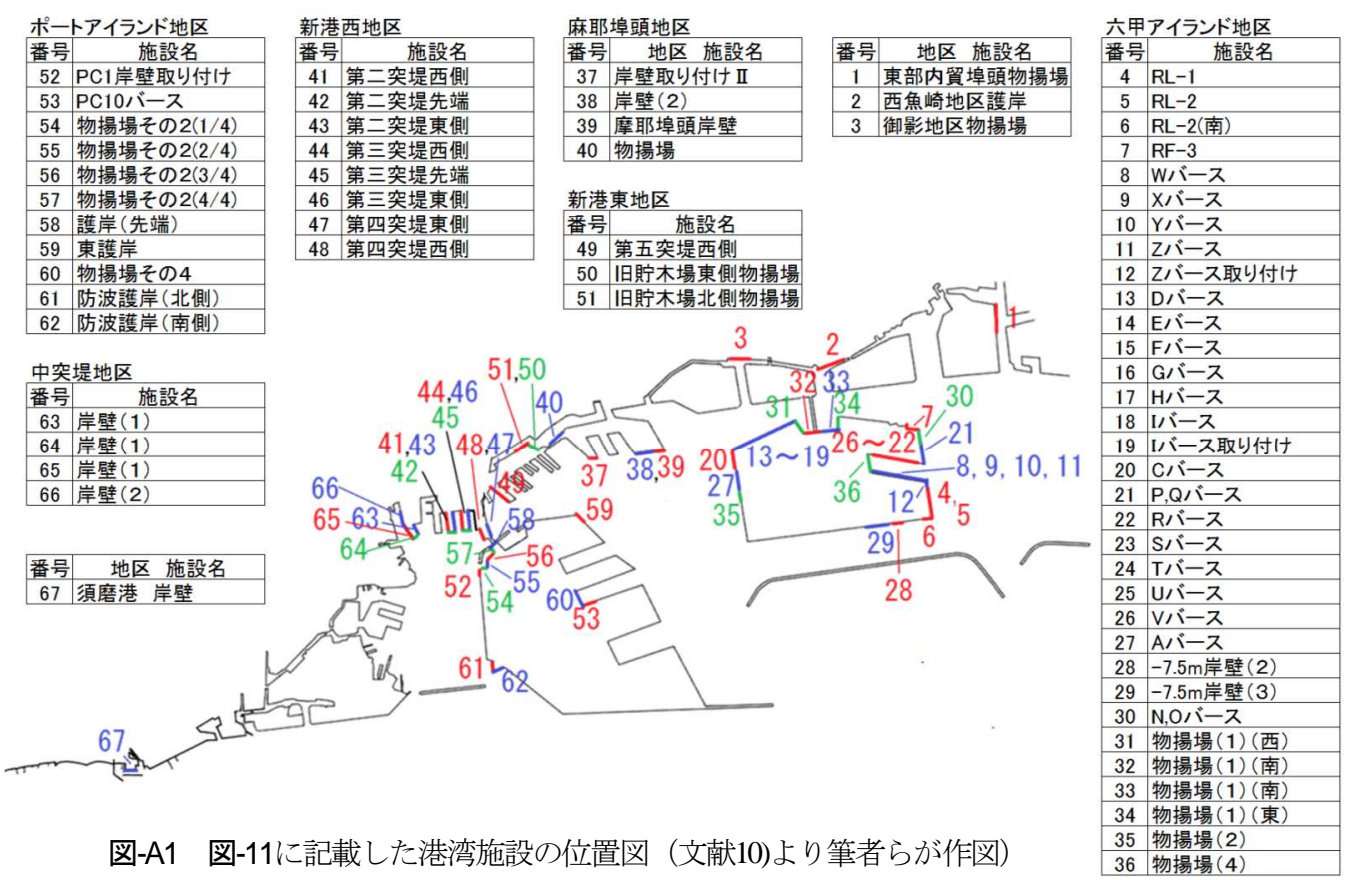

図-A1 図-11に記載した港湾施設の位置図（文献10)より筆者らが作図）

ただし，護岸の変形モードが倒壊したり，すべり破壊 を起こすようなものにならないことを確認するととも に，護岸の残留水平変位は $1.5 \mathrm{~m}$ 程度に抑えておくこと が望ましい.

・護岸の傾きに対する照査基淮としては，港湾施設の被 害程度川に対応した $8^{\circ}$ を照査基準とすることが考えら れる.

・延長の長いコンクリート重力式の護岸の中間部分につ いて, 目地開き量を推定する手法を提案した。

・提案した照査基準に基づく海岸護岸の改良設計のフロ 一を示した.

・実施中の海岸保全施設の整備事業を対象に考察した照 査基淮に基づく改良断面を設計し，その事例を示した。 ただし，本研究で提案した照査基準などは，1995年兵 庫県南部地震の施設延長が $100 \mathrm{~m}$ 以上の根入れの無いコ ンクリート重力式の港湾施設の被災事例をもとに提案し たものである. また，水平変位が極端に抑制されるよう な隅角端に対しての適用性は十分ではないと考えられる。 本研究によって重力式海岸護岸の最大水平変位の限界值 を従来よりも幾らか大きく設定することができると考え られるが, 残留水平変位は護岸の変形解析によって求め られることから, 如何に妥当な変形解析を行うかが従来 にも増して重要になるものと考えられる. 本研究の成果 を海岸護岸に対して適用寸る場合には，これらの点に注 意が必要である.

謝辞 : 本研究の題材となった撫養港海岸直轄海岸保全施 設整備事業においては，その立ち上げ時期に井合進 京 都大学名誉教授（一般社団法人 FLIPコンソーシアム理 事長) を委員長とした整備検討委員会を設置し，ご指導
をいただきました．本研究はその際の議論を元に執筆者 らの見解をまとめたものです。ここに記して深謝します。 また, 本研究は1995年兵庫県南部地震後の詳細な被災調 查なくしては成立しませんでした，当時，自らも被災さ れながら被災調查やその後の神戸港の復旧，復興に尽力 された皆様にあらためて尊敬と感謝の念を捧げます。併 せて，東日本大震災の被災調査，復旧，復興に尽力され ている皆様にも尊敬と感謝の念を捧げます。

\section{付録}

図-11に記載した港湾施設の位置を図-A1に示す.

\section{参考文献}

1) 海岸保全施設技術研究会編：海岸保全施設の技術上 の基準・同解説， 2004.

2) 日本港湾協会：港湾の施設の技術上の規準 - 同解説, pp. 935-936, 2007.

3) 一井康二, 井合進, 森田年一: 兵庫県南部地震にお けるケーソン式岸壁の挙動の有効応力解析, 港湾技 術研究所報告, Vol. 36, No. 2, pp. 41-86, 1997.

4) Iai, S., Matsunaga, Y. and Kameoka, T.: Strain space plasticity model for cyclic mobility, Report of the Port and Harbour Research Institute, Vol. 29, No. 4, pp. 27-56, 1990.

5) 長尾毅, 藤村公宜, 森屋陽一: 護岸の保有性能評価 に関する研究, 土木学会海洋開発論文集, 第 20 巻, pp. 101-106, 2004.

6) 寺前大：「海岸法の一部を改正する法律」について, 海岸, pp. 3-7, 2015.

7) 海岸管理のあり方検討委員会 : 今後の海岸管理のあ り方についてとりまとめ, 2014.

8) 柴田亮, 諏訪義雄: 海岸保全施設の技術上の基準に ついて, 海岸, pp. 12-14, 2015.

9）神戸市：神戸港港湾施設復旧誌一阪神 - 淡路大震災 
をのりこえて（技術編）－，1998

10) 運輸省港湾技術研究所 : 1995 年兵庫県南部地震によ る港湾施設被害報告，港湾技研資料，No. 857, 1977.

11）国土交通省国土政策総合研究所，国立研究開発法人 港湾空港技術研究所 : 平成 23 年(2011 年)東北地方太 平洋沖地震による港湾施設被害報告, 国土技術政策 総合研究所資料, No. 798, 港湾空港技術研究所資料, No. 1291, 2015.

12) Ishihara, K., Yasuda, S. and Nagase, H.: Soil characteristics and ground damage, Special Issue of Soils and Foundations, Japanese Geotechnical Society, pp. 109-118, 1996.

13）小笠原正史，角田浩，牧田篤弘，坂本俊一，松尾隆 志：地盤の側方流動を受ける基礎構造物の設計手法, 土木学会構造工学論文集, Vol. 44A, pp. 1623-1628, 1998.

14）井合進，堤達也，鈴木信久：講座 液状化に伴う地盤 の流動と構造物への影響 5. 地盤の流動を考慮した構 造物の設計（その 1），土と基礎，Vol. 48, No. 1, pp. 45-50, 2000.

15）井合進，堤達也，鈴木信久：講座 液状化に伴う地盤 の流動と構造物への影響 5.地盤の流動を考慮した構 造物の設計（その 2）, 土と基礎, Vol. 48, No. 2, pp. 41-46,2000.

16）小泉哲也，山本修司，竹地晃一郎，門脇陽治：被災 した残存耐力の評価手法の開発，港湾技研資料，No. 912, 1998.

17）上部達生：地震被災事例に基づく重力式および矢板 式係船岸の被災変形量と被災額の推定, 港湾技研資 料, No. 473, 1983.

18）藤野正宏，深田久：施工報告海岸堤防の耐震化一撫 養港海岸堤防における SAVE-SP 工法の適用(特集 地 震防災のための地盤改良)，土木施工，Vol. 52, No. 12, pp. 34-37, 2011.

19）中央防災会議事務局，中央防災会議「東南海，南海 地震等に関する専門調査会」(第 7 回)図面集，2002.12.

20) 長尾毅, 平松和也, 曽根照人, 野津厚 : 捶養港海岸 における入力地震動のゾーニングに関する研究, 土 木学会海洋開発論文集, 第 23 巻, pp. 805-810, 2007.

21）釜江克宏, 入倉孝次郎, 福知保長 : 地震のスケーリ ング則に基づいた大地震時の強震動予測一統計的波 形合成法による予測, 日本建築学会構造系論文報告
集，No. 430, pp. 1-9, 1991.

22) 後藤智明, 佐藤一央：三陸沿岸を対象とした津波数 值計算システムの開発, 港湾空港技術研究所報告, Vol. 32, No. 2, pp. 3-44, 1993.

23）小堤治, 塩崎禎郎, 一井康二, 井合進, 森玄：二次 元有効応力解析法の解析精度向上に関寸る検討, 海 洋開発論文集，第 20 巻, pp. 443-448, 2004.

24) 高野大樹 : 先端技術研究 静的圧入締固め(CPG)工法に よる地盤の締固め(特集 締める), 土木技術，Vol. 70, No. 10, pp. 26-31, 65, 2015.

25）大塚誠，磯谷修二：新工法 SAVE-マリン工法一強制 昇降装置と摇動装置を用いた環境対応型の地盤改良 工法，建設機械，Vol. 39, No. 8, pp. 58-61, 2003.

26）山崎浩之：液状化対策としての締固め工法の設計法 に関する研究, 港湾空港技術研究所資料, No. 1220, 2008.

27) 財団法人沿岸技術研究センター：液状化対策として の性的圧入締固め工法技術マニュアルーコンパクシ ヨングラウチング工法一, 2007.

28) 水山高久, 阿部宗平, 矢島重美 : スリット砂防ダム の流量係数と堆砂形状, 新砂防, Vol. 42, No. 4 (165), 1989.

29）酒谷幸彦，西川一，貝塚和彦，伊藤隆郭，長山孝彦, 田方智, 水山高久：スリット堰堤のスリット部周辺 の水理特性, 砂防学会研究発表会概要集, pp. 454-455, 2010.

30) 塚本博紀, 野获秀夫, 渡部春樹, 長山高彦, 小川和 彦，杉山実，伊藤隆郭，渡邊康玄：スリットえん堤 の流況を再現するための模型実験に関する研究，第 65 回土木学会年次学術講演会講演概要集 (CD-ROM), 2010.

31) 河合弘泰, 竹村慎治, 原信彦: 東京湾における台風 による高潮と高波の同時性と継続時間特性，海岸工 学論文集, 第 49 巻, pp. 251-255, 2002.

32) 山口正隆, 大福学, 畑田佳男：高波の計測時間の統 計的特性とその推定法, 海岸工学論文集, Vol. 40, pp. 116-120, 1993.

(2017.5. 30 受付)

\title{
A PROPOSAL ON THE SEISMIC PERFORMANCE CRITERIA TO SEA WALLS BASED ON THE OBSERVED DAMAGE CASES IN 1995 HYOGOKEN-NANBU EARTHQUAKE
}

\author{
Katsuhiko KOIZUMI, Koji ICHII, Akito SONE, Toshiyuki HIRAI, \\ Koichi MURAKAMI and Minoru YAMANAKA
}

The concept of performance-based seismic design has been introduced in the 2004 revision and 2007 revision of the Japanese design codes for coastal structures and port structures, respectively. However, the performance criteria for coastal structures is given as the allowable settlement at the crest of the seawalls, and there is no discussion on the allowable horizontal displacement. In reality observed in 1995 Hyogoken-Nanbu earthquake disaster, some seawalls lost their function of continuous walls due to uneven horizontal displacement of the walls. Thus, in this paper, the allowable level of horizontal displacement of seawalls is discussed from the observed damage cases, and the performance criteria is proposed. Then, the feasibility of the proposal was discussed in detail with a project of the remediation of sea walls. 